\title{
Synthesis of Bicyclic Alkene-/Alkane-Bridged Nisin Mimics by Ring-Closing Metathesis and their Biochemical Evaluation as Lipid II Binders: toward the Design of Potential Novel Antibiotics
}

\author{
Nourdin Ghalit, ${ }^{[a, c]}$ John F. Reichwein, ${ }^{[a, d]}$ Hans W. Hilbers, ${ }^{[a]}$ Eefjan Breukink, ${ }^{[b]}$ \\ Dirk T. S. Rijkers, ${ }^{[a]}$ and Rob M. J. Liskamp ${ }^{*[a]}$
}

\begin{abstract}
This report describes the design, synthesis, and biochemical evaluation of alkene- and alkane-bridged $A B(C)$-ring mimics of the lantibiotic nisin. Nisin belongs to a class of natural antimicrobial peptides, and has a unique mode of action: its $A B(C)$-ring system binds to the pyrophosphate moiety of lipid II. This mode of action was the rationale for the design of smaller nisin-derived peptides to obtain novel potential antibiotics. As a conformational constraint the thioether bridge was mimicked by an alkene- or alkane isostere. The peptides of the linear individual ring precursors were synthesized on solid support or in solution, and cyclized by ring-closing metathesis in solution with overall yields of be-
\end{abstract}

tween 36 and $89 \%$. The individual alkene-bridged macrocycles were assembled in solution by using carbodiimide-based synthesis protocols for the corresponding $A B(C)$-ring mimics. These compounds were tested for their binding affinity toward lipid II by evaluation of their potency to inhibit nisin-induced carboxyfluorescein release from large unilamellar vesicles. It was found that these $A B(C)$-ring mimics were not able to induce membrane leakage; however, they acted by inhibiting nisin-induced carboxyfluorescein release; this indicates their affinity toward lipid II. These results imply that an alkene or alkane moiety is a suitable thioether bridge mimic.

\section{Introduction}

Nisin (Scheme 1) belongs to a class of natural antimicrobial peptides called lantibiotics, which are produced by a broad range of bacteria, for example, Bacillus, Lactococcus, Streptomyces, and Staphylococcus species. ${ }^{[1]}$ A general feature of these peptides is the presence of a lanthionine moiety (a thioether or sulfide bridge; Scheme 2) that gives them their specific bioactive conformation. ${ }^{[2]}$

Nisin binds with its $N$ terminus, which consists of the $A B(C)$ ring system, to lipid II (Scheme 3). This enables the $C$ terminus, which consists of the knotted DE-ring system, to form pores in the phospholipid membrane, which ultimately lead to cell leakage and collapse of the vital ion gradients across the membrane. ${ }^{[3]}$

Lipid ${ }^{\left[{ }^{[4]}\right.}$ is an essential precursor for cell-wall synthesis. ${ }^{[5]}$ It consists of two amino sugars, $\mathrm{N}$-acetyl glucosamine (GlcNAc) and $\mathrm{N}$-acetyl muramic acid (MurNAc), and a pentapeptide (usually H-Ala-D-Glu(Lys-D-Ala-D-Ala-OH)-OH-) that is attached to the carboxyl moiety of MurNAc. This glycopeptide is coupled via a pyrophosphate group to undecaprenol-a membraneanchored carrier-to yield lipid II. The Lys-D-Ala-D-Ala-OH peptide fragment is recognized by a transpeptidase that forms interstrand peptide cross-links. ${ }^{[6]}$ This cross-linking gives the bacterial cell wall its mechanical strength. The lysine residue, present in Gram-positive bacteria, is replaced by a meso-diamino- pimelate ( $m$-DAP) moiety in Gram-negative bacteria. ${ }^{[6 c]}$ Lipid II is an important target for many antimicrobial peptides, such

[a] Dr. N. Ghalit, Dr. J. F. Reichwein, H. W. Hilbers, Dr. D. T. S. Rijkers, Prof. Dr. R. M. J. Liskamp

Medicinal Chemistry \& Chemical Biology

Utrecht Institute for Pharmaceutical Sciences

Department of Pharmaceutical Sciences

Faculty of Science, Utrecht University

P.O. Box 80082, 3508 TB Utrecht (The Netherlands)

Fax: $(+31) 30-253-6655$

E-mail: r.m.j.liskamp@pharm.uu.nl

[b] Dr. E. Breukink

Chemical Biology and Organic Chemistry

Bijvoet Center for Biomolecular Research

Department of Chemistry, Faculty of Science, Utrecht University

P. O. Box 80082, 3508 TB Utrecht (The Netherlands)

[c] Dr. N. Ghalit

Present address: SABIC-Europe

P.O. Box 319, 6160AH Geleen (The Netherlands)

[d] Dr. J. F. Reichwein

Present address: Encysive ${ }^{\mathrm{TM}}$ Pharmaceuticals

7000 Fannin

Houston, TX 77030 (USA)

Supporting information for this article is available on the WWW under http://www.chembiochem.org or from the author. 

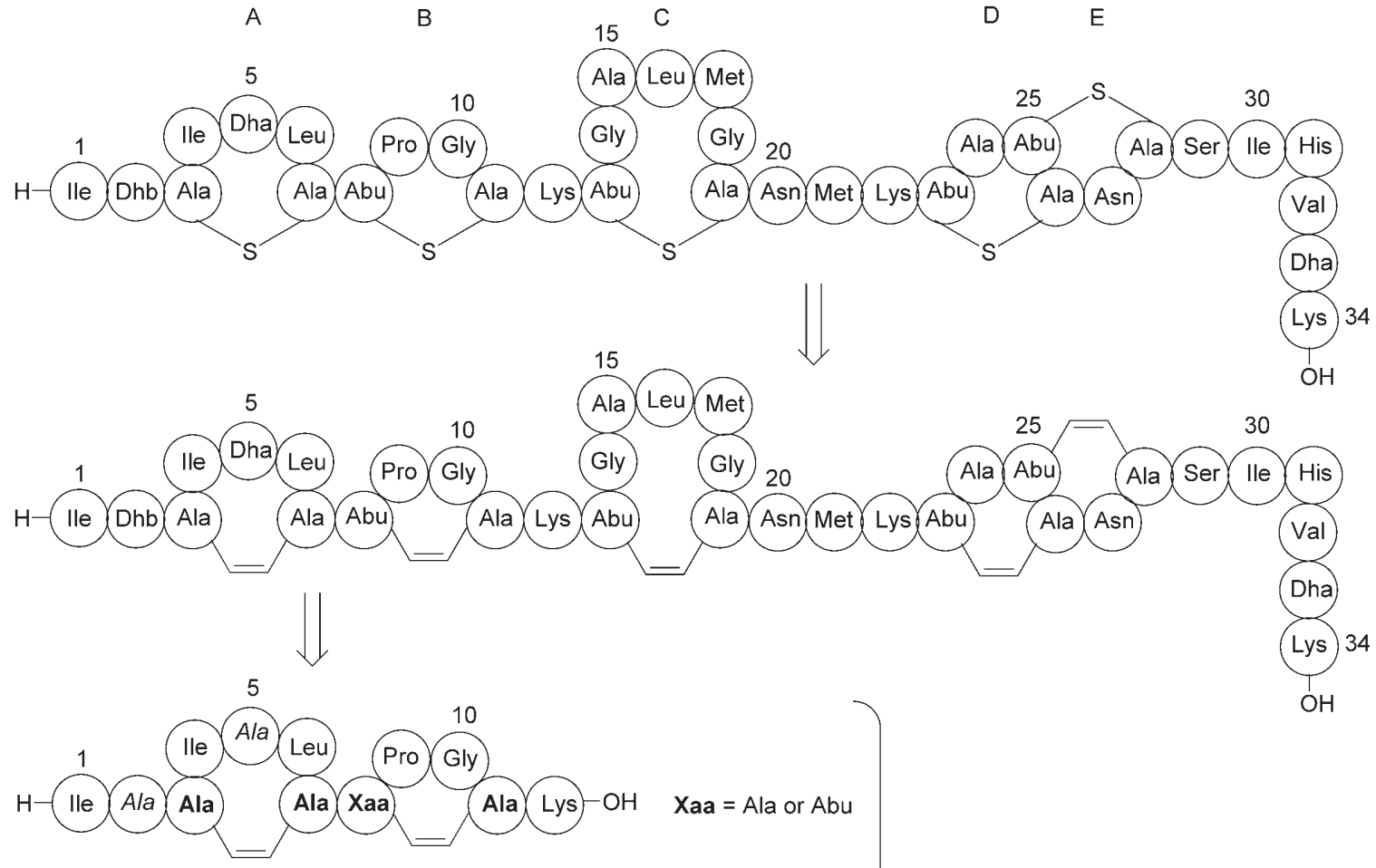

and

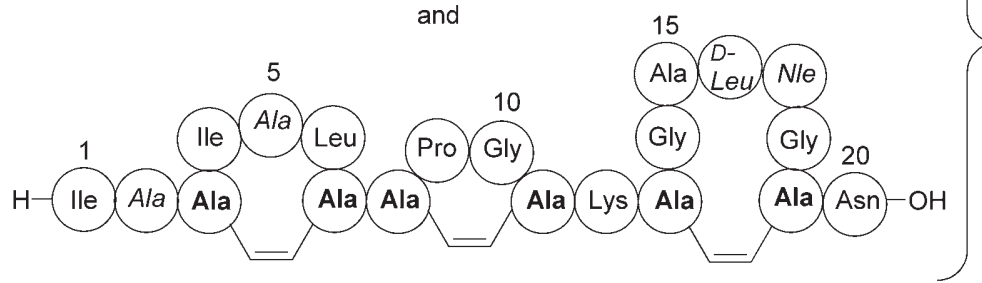

Synthesis, and binding studies toward lipid II

Scheme 1. Schematic representation of nisin (top) and its alkene-bridged mimics. Dhb: dihydrobutyrine; Dha: dehydroalanine; Nle: norleucine; Abu: $\alpha$-aminobutyric acid. The italicized amino acids represent those changed in the alkene/alkane mimics as compared to the nisin $A B(C)$ fragments. The bold amino acids represent the bridge heads, which are, of course, no longer actual Ala or Abu residues.

as vancomycin, ramoplanin, and nisin, and is a target for the development of new antibiotics. ${ }^{[7,8]}$

Recently, the molecular mechanism of the nisin-lipid II interaction has been unraveled by NMR spectroscopy studies. ${ }^{[9]}$ It has been found that nisin binds the pyrophosphate moiety of the so-called "pyrophosphate cage" that is formed by the peptide backbone of the $A B(C)$-ring system. Binding of the $A B(C)$ fragment to lipid II also results in antimicrobial activity, although to a lesser extent than full-length nisin. ${ }^{[10]}$ It is thought that this binding interferes with the cross-linking in the peptidoglycan network in the bacterial cell wall. ${ }^{[10 b, 11]}$ The formation of this complex implies that any molecule that has a binding affinity toward lipid II is a potential antibiotic. ${ }^{[8]}$

We were interested to investigate whether the repertoire of Nature, with respect to conformational constraints, such as disulfide or thioether bridges, could be extended to other promising constraints, in particular alkane-, alkene-, or alkyne constraints. ${ }^{[12]}$ We describe here the design, synthesis and biochemical evaluation of nisin-derived $A B(C)$-ring mimics 1-7 (Scheme 4) for the development of novel peptide-based antibiotics.

\section{Results and Discussion}

\section{Rationale for the design}

The lipid II-nisin interaction is dictated by the peptide backbone of the $A B(C)$ fragment, as recently shown by Hsu et al. ${ }^{[9]}$ Replacement of the thioether moiety by alkane-, alkene-, or alkyne cyclic constraints might result in peptide mimics of nisin with improved binding properties and/or increased metabolic stability. ${ }^{[12,13]} \mathrm{A}$ potential isostere of the thioether bridge is the alkene bridge; this can be introduced with ring-closing metathesis $(\mathrm{RCM})^{[14]}$ by using amino-acid residues that have a terminal alkene moiety in their side chain. $\mathrm{n}$ this study, lanthionine and 3-methyllanthionine (Scheme 2 ) were replaced by an alkene $(\mathbf{1}, \mathbf{3})$ or alkane (2) bridge, respectively, which were formed from two L-allylglycine residues (Scheme 4). As (3methyl)lanthionine is formed from a combination of a $\mathrm{D}$ - and L-amino-acid residue, ${ }^{[15]}$ two additional alkene-bridged mimics (4 and 6) were designed and synthesized. Compound 4, an alkene mimic with a backbone stereochemistry identical to that of nisin, was obtained from a RCM-precursor that had a combination of D- and L-allylglycine residues. Compound $\mathbf{6}$ not only had the same backbone stereochemistry as nisin, but also 

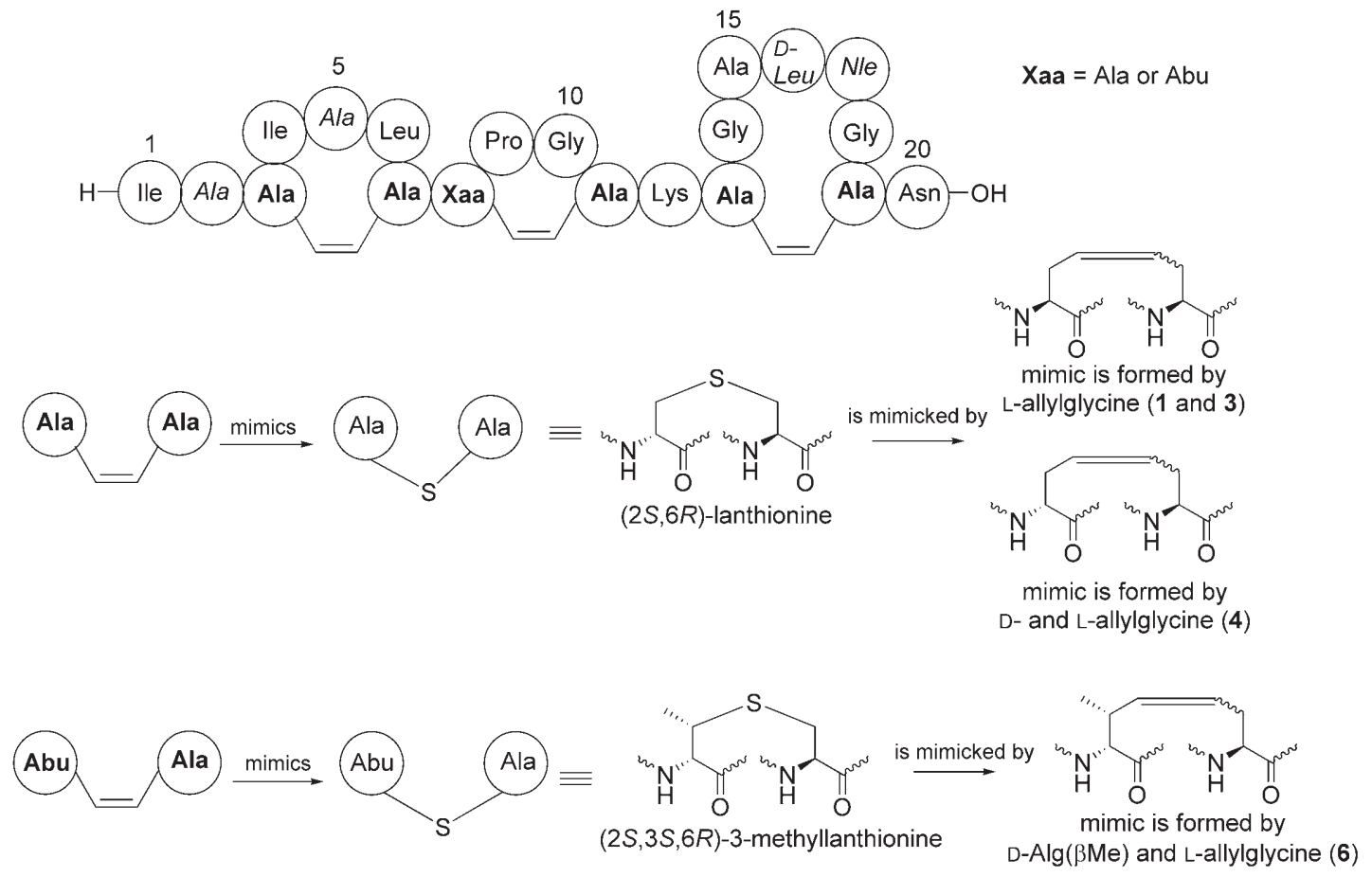<smiles>C=CC[C@H](N)C(=O)O</smiles>
(S)-2-amino-4-pentenoic acid L-allylglycine<smiles>C=CC[C@H](N)C(=O)O</smiles>
(R)-2-amino-4-pentenoic acid D-allylglycine<smiles>C=C[C@H](C)[C@H](N)C(=O)O</smiles>
$(2 R, 3 R)$-2-amino-3-methyl-4-pentenoic acid $\mathrm{D}-\mathrm{Alg}(\mathrm{BMe})$

Scheme 2. Structures of the $(2 S, 6 R)$-lanthionine and $(2 S, 3 S, 6 R)-3$-methyllanthionine moieties and their corresponding alkene-bridged mimics formed by $(S)-2-$ amino-4-pentenoic acid, $(R)$-2-amino-4-pentenoic acid, and (2R,3R)-2-amino-3-methyl-4-pentenoic acid. Note: the configuration of the chiral centers is the same; their $R / S$ signs are opposite due to the CIP rules. The italicized amino acids represent those changed in the alkene/alkane mimics as compared to the nisin $A B(C)$ fragments. The bold amino acids represent the bridge heads, which are, of course, no longer actual Ala or Abu residues.

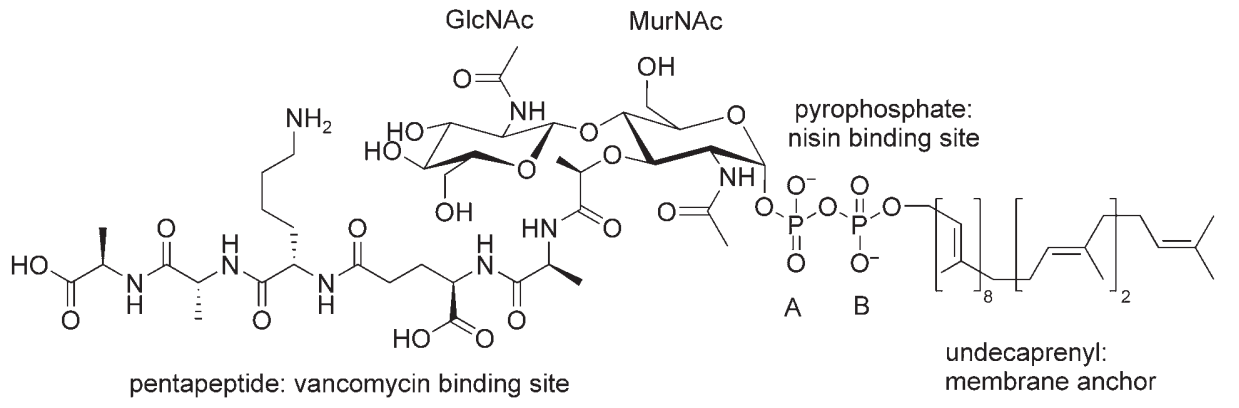

Scheme 3. Structural formula of lipid II.

the same side-chain stereochemistry. For the synthesis of this alkene-bridged 3-methyllanthionine mimic, a $\beta$-methyl-substituted D-allylglycine residue, was prepared. ${ }^{[16]}$ This was incorporated with an L-allylglycine residue, followed by RCM. To avoid any $E / Z$ conformational effects, 4 and 6 were reduced to their alkane-bridged congeners 5 and 7, respectively.

\section{Synthesis}

Synthesis strategy: Retro-synthesis analysis shows that a mimic of the $A B(C)$ fragment should be attainable by the coupling of three cyclic alkene-bridge-containing peptides. To simplify the synthesis, dihydrobutyrine $(\mathrm{Dhb})^{[10 a]}$ and dehydroalanine $(D h a)^{[17]}$ residues (fragment A) were replaced by alanine residues, and the methionine residue (fragment $\mathrm{C}$ ) was replaced by norleucine (Nle). ${ }^{[18]}$ It has been shown that these chemically more resistant residues do not influence the biological activity of full-length nisin. ${ }^{[10 a, 17]}$ Thus, our strategy for the total synthesis of the mimics of the $A B(C)$ fragment consisted of linear synthesis of the peptide sequences of the three individual ring fragments, either on solid phase or in solution, followed by ring-closing metathesis (RCM) in solution by using second generation Grubbs' catalyst. ${ }^{[19]}$ After that, the $A B(C)$ mimics were assembled by coupling the cyclized fragments in solution. ${ }^{[20]}$

Synthesis of $A B(C)$ fragment mimics 1-3: The linear peptide 11 , that is, the RCM-precursor of fragment $A$, was synthesized on plain ArgoGel resin loaded with Fmoc-Alg-OH (8) by using 


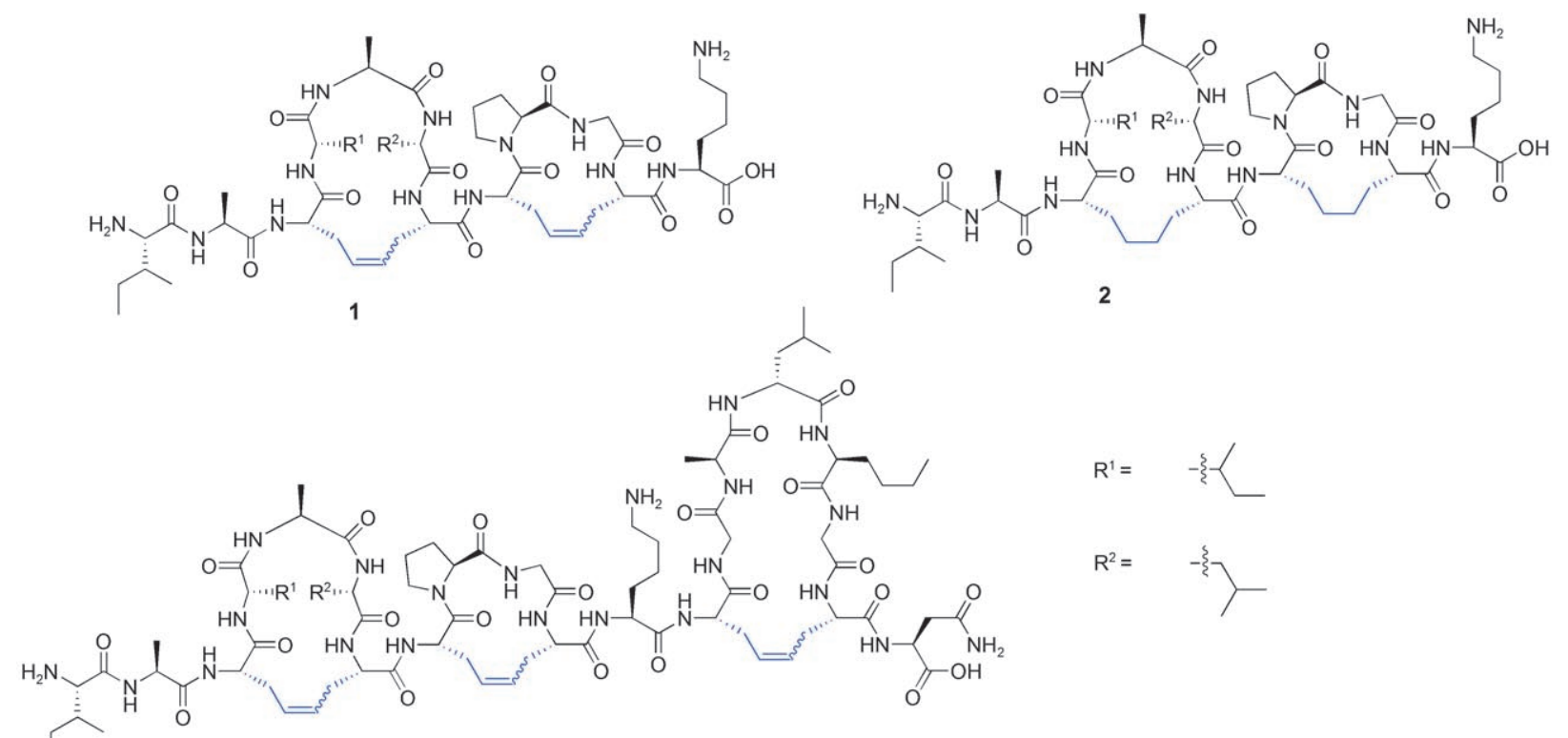

3

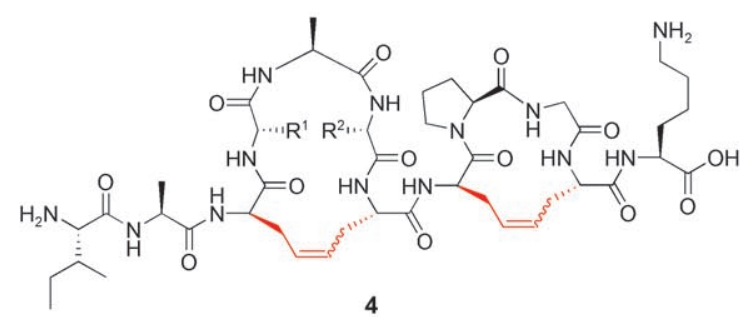

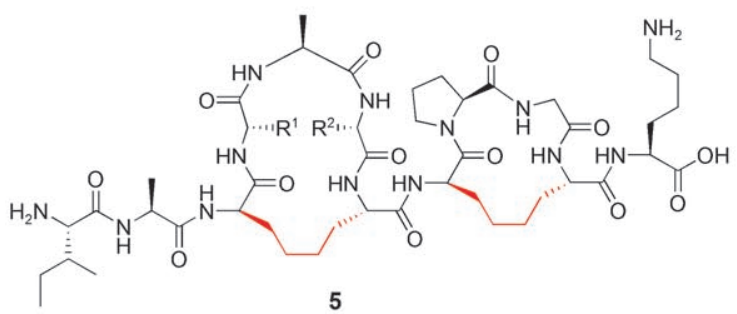

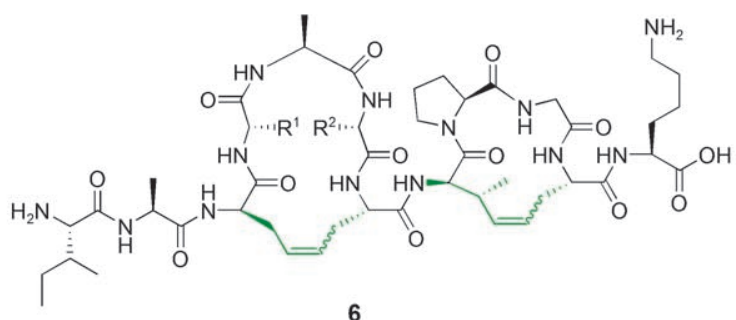

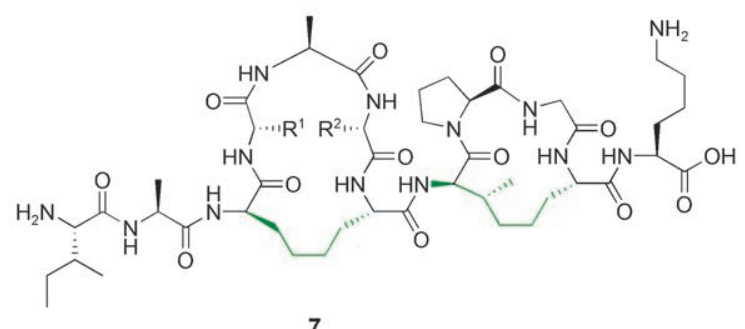

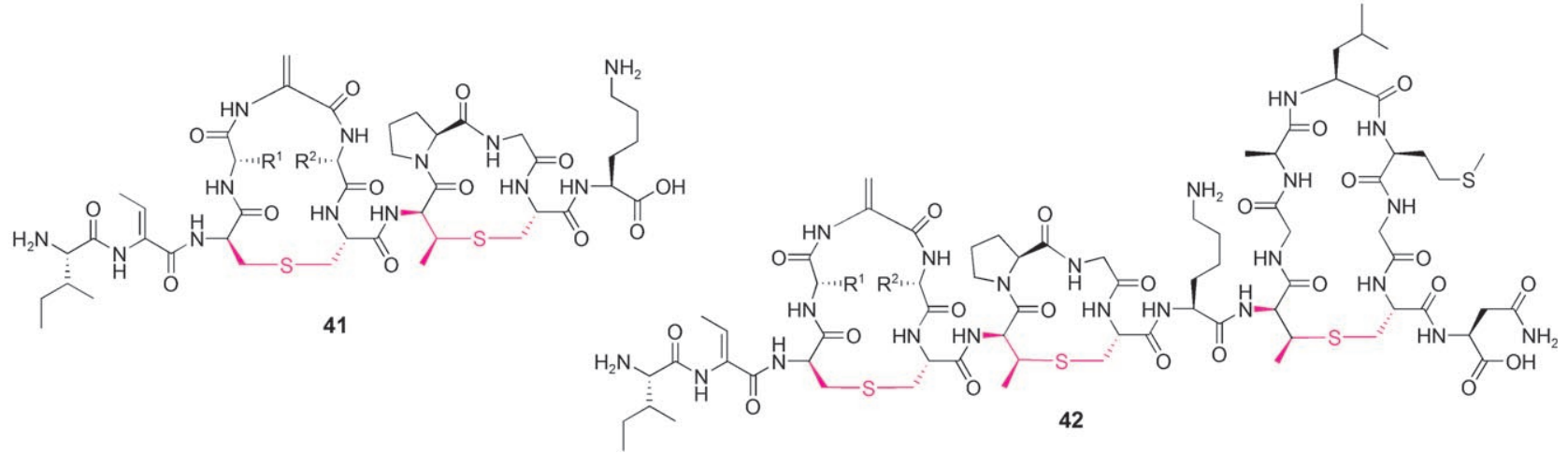

Scheme 4. Structural formulae of the alkene- and alkane-bridged mimics 1-7 of the nisin $A B(C)$ fragments. Compound 41 is the natural $A B$ fragment. The colored fragments highlight the alkene/alkane bridges (blue, red, and green), which mimic the two ether bridges (magenta) of the nisin $A B(C)$ fragment.

Fmoc/tBu solid-phase synthesis (Scheme 5). Peptide 11 was obtained as the protected $\mathrm{N}^{\alpha}$-Boc heptapeptide methyl ester after cleavage by treatment of the resin with KCN in methanol. The poor solubility of this fragment hampered cyclization, since DMF, which was necessary as a cosolvent, deactivated the RCM catalyst; ${ }^{[21]}$ consequently, 12 was isolated in low yield (6\%). Therefore, the strategy was adjusted and the shorter, more soluble, pentapeptide 9 was synthesized; this led to 


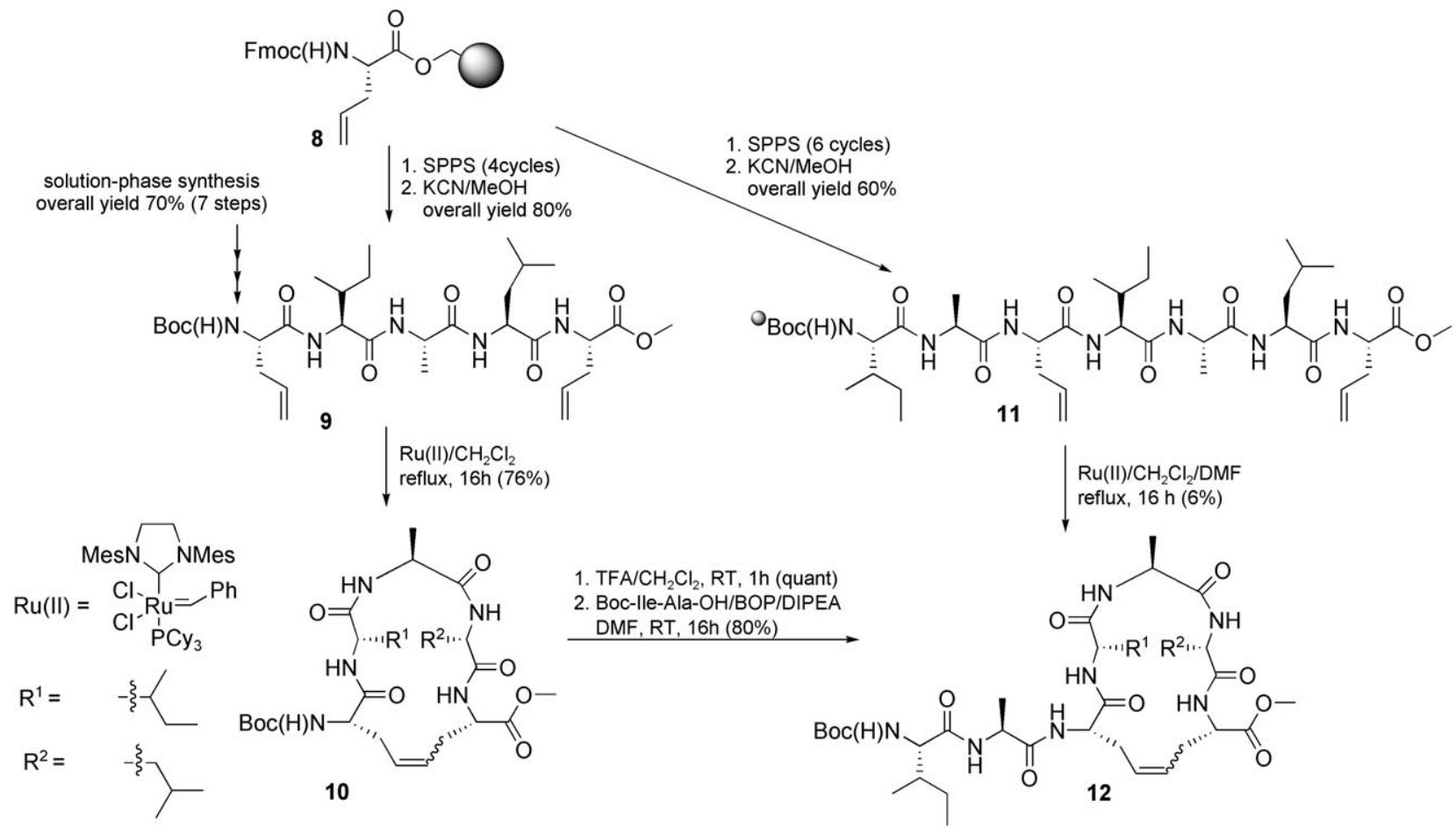

Scheme 5. Synthesis of the alkene-bridged A-ring mimic 12.

cyclic peptide 10 after RCM, in good yield (76\%). At this stage the $E / Z$ isomers could be only partially separated by column chromatography; thus, it was decided to continue the synthesis with the mixture of isomers. The product was obtained with an $E: Z$ ratio of $1: 2.8$. The $E$ isomer was assigned by using multiple-decoupling NMR spectroscopy ${ }^{[22]}\left(J_{A B}\right.$ : $\left.15.3 \mathrm{~Hz}\right)$. Unfortunately, the $J$ value of the $Z$ isomer could not be determined due to the absence of a well-defined multiplet. Cyclic peptide 10 (as E/Z mixture) was treated with TFA to remove the Boc group and coupled to dipeptide Boc-lle-Ala-OH. The desired fragment $A$ (12) was obtained in an overall yield of $80 \%$. $^{[23]}$

For the synthesis of fragment $B(15)$, protected pentapeptide 14 was prepared from resin 13 by treatment of the peptide resin with a catalytic amount of $\mathrm{KCN}$ in methanol (Scheme 6). Not entirely unexpectedly, the isolated yield was rather low $(13 \%)$, mainly due to cleavage of the Fmoc group under these relatively basic conditions.

Therefore, it was decided to synthesize the RCM precursor 14 in solution by coupling Fmoc-Alg-Pro-Gly-OH (16) to FmocAlg-Lys(Boc)-OMe (17). Although amine 18 was prone to diketopiperazine formation ${ }^{[24]}$ during the coupling with peptide acid 16, the overall yield was better (36\%) than for solid-phase synthesis (13\%). Cyclization of 14 was performed by refluxing DCM in the presence of Ru catalyst to obtain 15 in $85 \%$ yield. The product appeared pure by TLC and HPLC; however, NMR analysis clearly showed the presence of several conformational isomers.

For the assembly of fragment $C$, protected heptapeptide 19 was prepared by solid-phase synthesis (Scheme 7). Unfortunately, attempts to cyclize Boc-Alg-Gly-Ala-Leu-Nle-Gly-Ala-
OMe were unsuccessful. Incorporation of a D-Leu residue was necessary to achieve cyclization, and cyclic heptapeptide $\mathbf{2 0}$ was obtained by using $50 \mathrm{~mol} \%$ of second generation Grubbs' catalyst. Disappointingly, the cleavage yield of 19 from the solid support was unsatisfactory due to its low solubility in $\mathrm{MeOH}$. Thus, it was decided to synthesize heptapeptide 19 in solution from fragments Boc-Alg-Gly-OH and Boc-Ala-D-LeuNle-Gly-Alg-OMe (22). The latter was prepared from tetrapeptide Boc-Ala-D-Leu-Nle-Gly-OH (21) and HCl.H-Alg-OMe.

The $A B(C)$ fragment was assembled in solution as shown in Scheme 8 . Peptides 12, 15, and 20 were obtained as protected methyl esters since the cleavage from plain ArgoGel resin was performed with $\mathrm{KCN}$ in $\mathrm{MeOH}$. In the first fragment-coupling approach, attempts were made to convert the methyl esters into hydrazides by treatment with hydrazine hydrate. These hydrazides were converted in situ into azides for a racemizationfree coupling of the C-terminal amino-acid residue, as described by Curtius ${ }^{[25]}$ and modified by Honzl and Rudinger. ${ }^{[26]}$ However, the protected peptide hydrazides were found to be nearly insoluble. Moreover, treatment with hydrazine also reduced the double bonds of the alkene-bridged fragments 12, 15, and 20. Therefore, it was decided to convert the protected peptide methyl esters into their corresponding acids, which were then coupled to the amines by carbodiimide-based coupling reagents in the presence of HOBt to suppress racemization. ${ }^{[27]}$ Conversion of the peptide acids into their corresponding peptide azides with diphenylphosphorazidate ${ }^{[28]}$ did not achieve satisfactory yields, therefore, this was abandoned.

Cyclic peptide 12 was saponified with $\mathrm{LiOH}$ in $\mathrm{THF} / \mathrm{H}_{2} \mathrm{O},{ }^{[29]}$ and gave peptide acid 23 in $81 \%$ yield after workup. The Fmoc group of cyclic peptide $\mathbf{1 5}$ was removed by treatment 

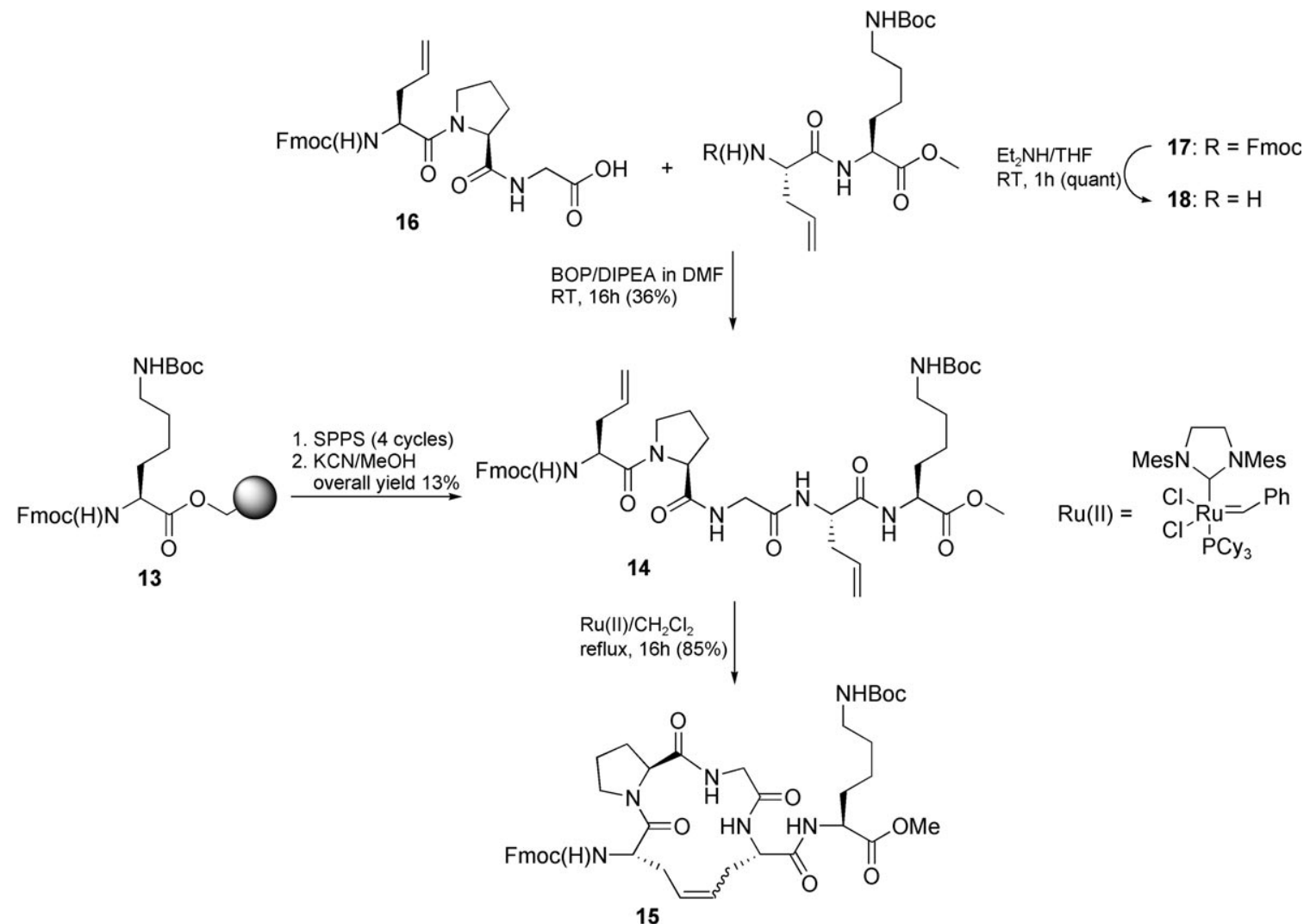

Scheme 6. Synthesis of the alkene-bridged B-ring mimic 15.

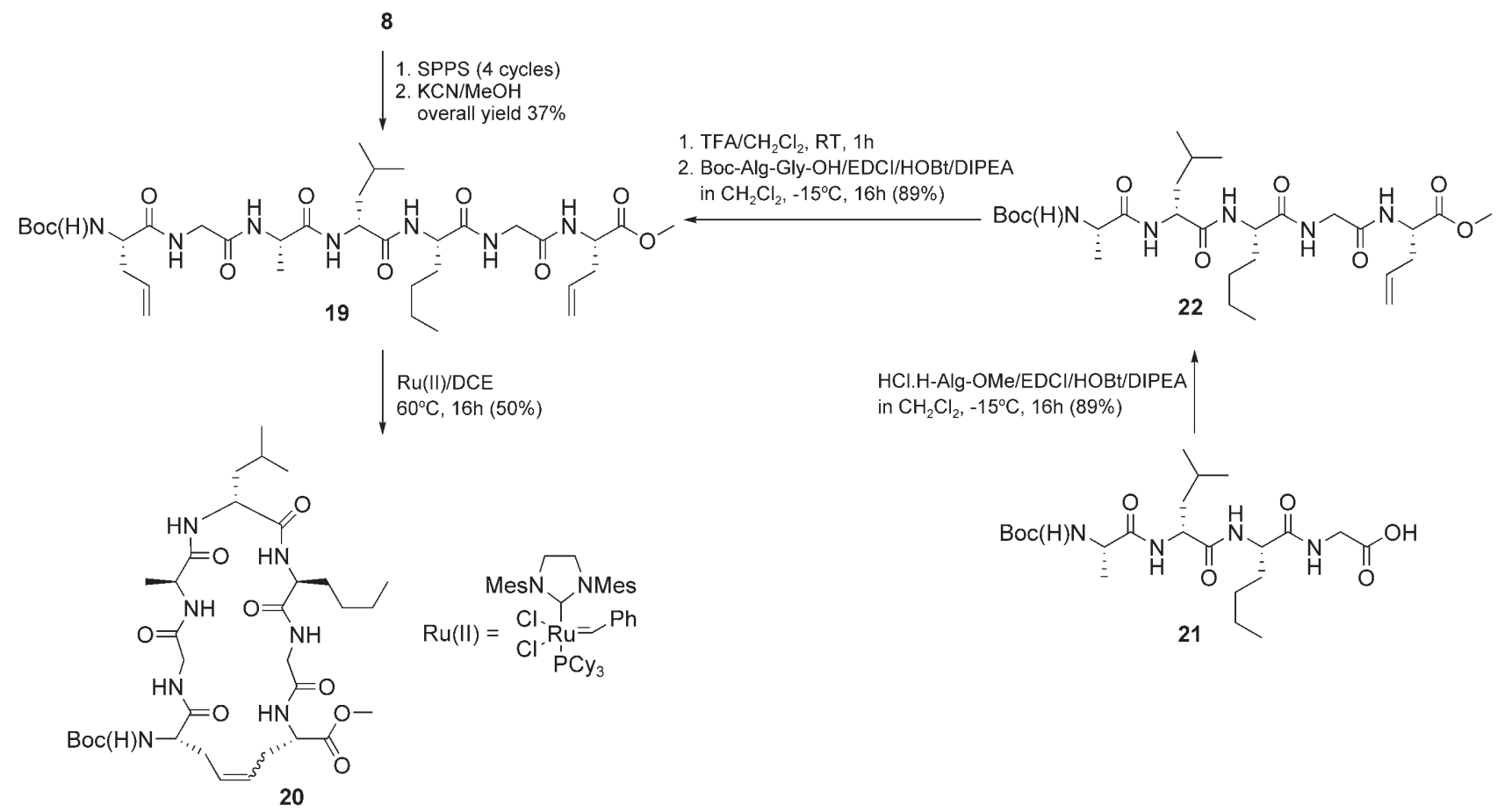

Scheme 7. Synthesis of the alkene-bridged C-ring mimic 20.

with aqueous dimethylamine, and $\mathbf{2 4}$ was obtained in a quantitative yield. The obtained alkene mimics of fragment $A$ and $B$ were coupled, overnight, by using $\mathrm{EDCl} / \mathrm{HOBt}^{[30]}$ as coupling re- agents in DMF at $-15^{\circ} \mathrm{C}$, and the bicyclic alkene mimic 25 of the $A B$ fragment was obtained in $65 \%$ yield. An aliquot of 25 was fully deprotected and characterized with LC-MS/MS ${ }^{[31]}$ and 


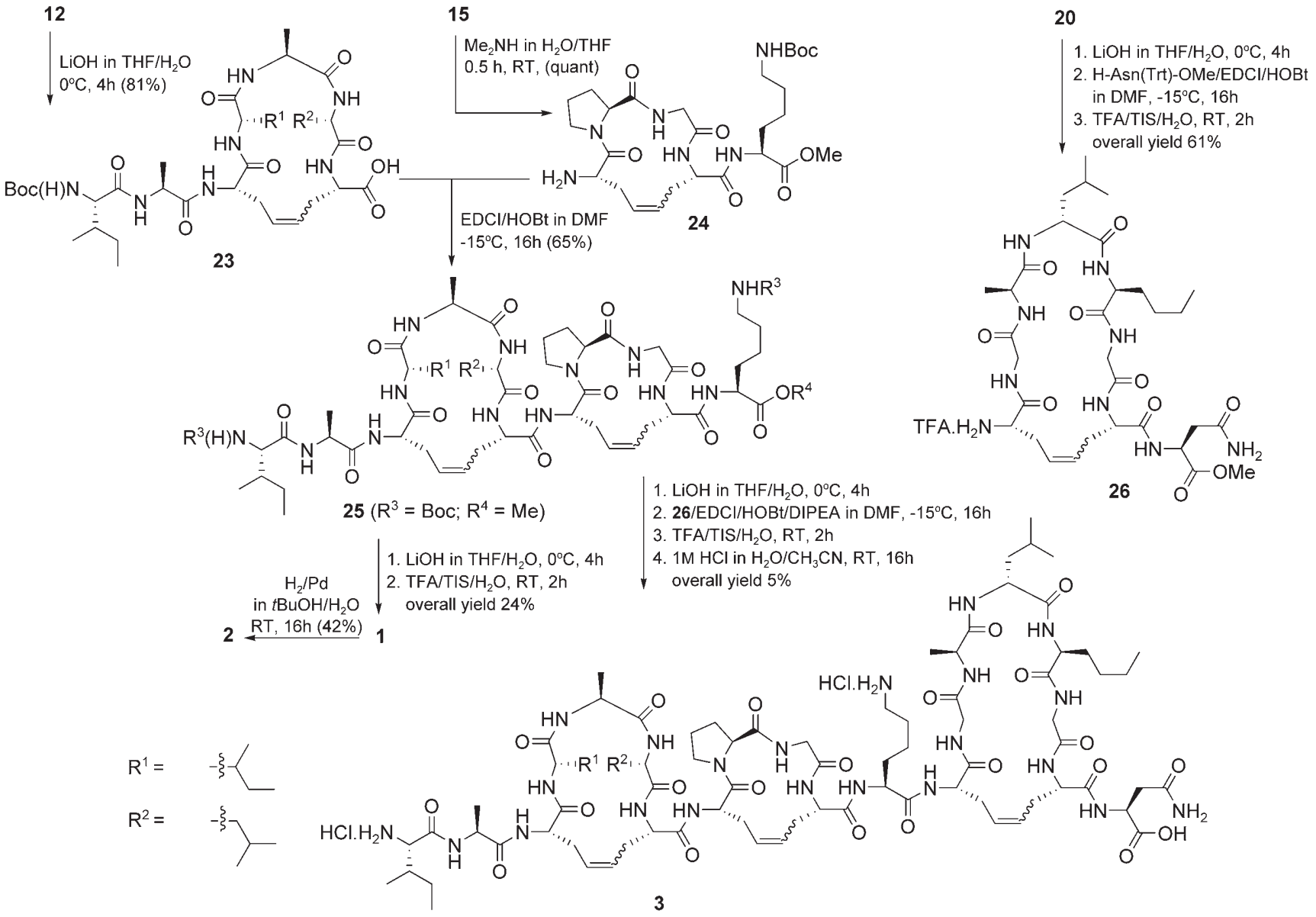

Scheme 8. Assembly of the tricyclic alkene-bridged ABC-ring mimic 3 from the individual cyclic-ring fragments 12,15 , and 20.

MALDI-TOF. The main portion of the $A B$ fragment mimic 25 was saponified with $\mathrm{LiOH}$ in $\mathrm{THF} / \mathrm{H}_{2} \mathrm{O}$ to give the corresponding peptide acid after acidic workup. Due to its low solubility, this compound was used without further purification.

The protected $A B$ fragment peptide acid was subjected to a second deprotection step in the presence of TFA and scavengers (TIS, $\mathrm{H}_{2} \mathrm{O}$ ) to remove both Boc groups, and the AB-ring mimic 1 was obtained. After purification by HPLC, 1 was obtained in $24 \%$ yield and characterized by mass spectrometry. A small portion was subsequently hydrogenated to give the alkane-bridged mimic 2 in $42 \%$ yield.

For final assembly of the $A B(C)$ mimic, cyclic peptide 20 was saponified with $\mathrm{LiOH}$ in $\mathrm{THF} / \mathrm{H}_{2} \mathrm{O}$. After workup and coupling to $\mathrm{H}$-Asn(Trt)-OMe, as described above, the corresponding cyclic octapeptide was treated with TFA/TIS/ $\mathrm{H}_{2} \mathrm{O}$ to remove the Boc and Trt groups. Peptide ester 26 was obtained in $61 \%$ overall yield after trituration with MTBE/hexane.

Finally, the saponified $A B$-ring mimic $\mathbf{2 5}$ and $C$-ring mimic 26 were coupled by using $\mathrm{EDCl} / \mathrm{HOBt}$ in $\mathrm{DMF}$ at $-15^{\circ} \mathrm{C}$, overnight, and the product was subjected to saponification of the methyl ester. However, this also resulted in dehydration of the carboxamide functionality of the asparagine residue to the corresponding cyano derivative, as evidenced by MALDI-TOF analysis, which showed a loss of $18 \mathrm{amu}^{[32]}$ To avoid dehydration, the crude reaction product was first treated with TFA/TIS $/ \mathrm{H}_{2} \mathrm{O}$ to remove the Boc functionalities, and then treated with $1 \mathrm{M}$ $\mathrm{HCl} / \mathrm{CH}_{3} \mathrm{CN}$ to hydrolyze the methyl ester. This resulted in isolation of tricyclic peptide mimic $\mathbf{3}$ as its hydrochloride salt. After purification by HPLC and analysis by mass spectrometry (ESMS, MALDI-TOF, and LC-MS/MS) the alkene-bridged mimic of the $A B C$-ring system 3 was obtained in $5 \%$ overall yield starting from 25 and 26.

Synthesis of $A B$ fragment mimics 4-7: The synthesis of 4-7 is shown in Schemes 9 and Scheme 10. Precursor peptide 27, which has an N-terminal D-allylglycine residue, was synthesized in solution starting from $\mathrm{HCl} \cdot \mathrm{H}-\mathrm{Alg}-\mathrm{OMe}$ in seven steps in $84 \%$ overall yield (Scheme 9A). RCM of precursor 27 proceeded with increased efficiency compared to its all-L diastereomer 9 (90 vs. $76 \%$ ). Cyclic peptide 28 was treated with TFA to remove the Boc functionality, and the amine was subsequently coupled to Boc-lle-Ala-OH in the presence of $\mathrm{EDCl} / \mathrm{HOBt}$ at $-15^{\circ} \mathrm{C}$ to minimize racemization of the alanine residue; ${ }^{[30]}$ peptide 29 (fragment A) was obtained in $47 \%$ yield.

In the next step, the $B$ fragments, which were represented by 34 (lanthionine mimic) and 35 (3-methyllanthionine mimic), were prepared by starting from the general precursor peptide 31 (Scheme 9B). Peptide $\mathbf{3 1}$ was synthesized by BOP-mediated coupling in $80 \%$ yield from dipeptides Fmoc-Pro-Gly-OH (30) and H-Alg-Lys(Boc)-OMe (18). The latter was obtained from 17 after treatment with diethylamine to remove the Fmoc group. 

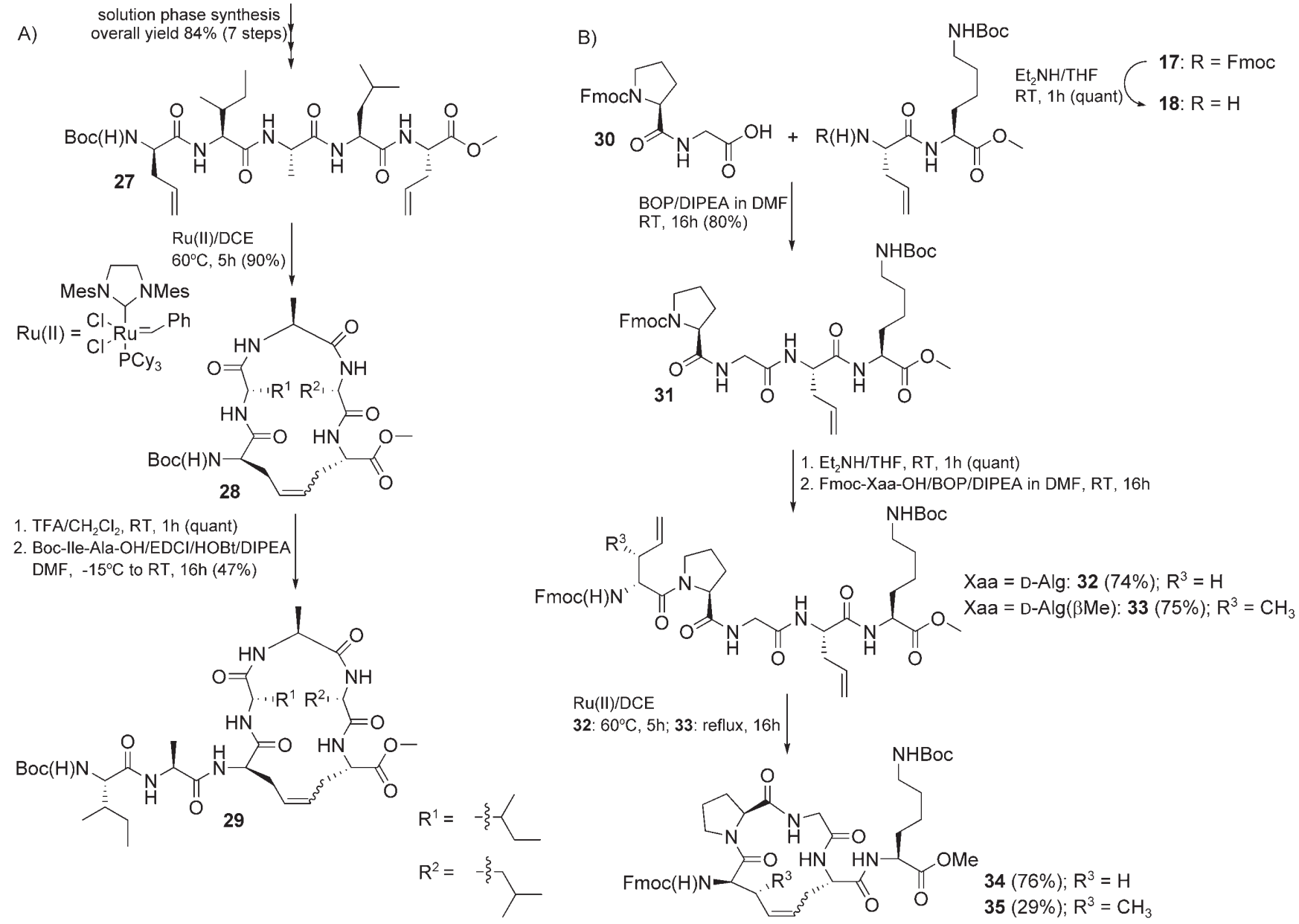

$\mathrm{Ru}(\mathrm{II}) / \mathrm{DCE}$
32: $60^{\circ} \mathrm{C}, 5 \mathrm{~h} ; 33$ : reflux, 16h

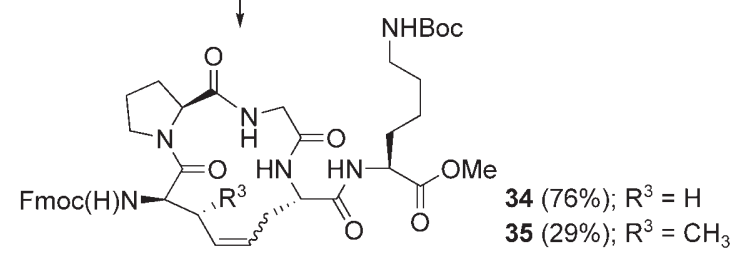

Scheme 9. Synthesis of the alkene-bridged AB-ring mimics with the stereochemistry of native nisin in the peptide backbone/side chain. A) Synthesis of fragment $A ; B$ ) synthesis of fragment $B$.

Tetrapeptide 31 was also treated with $\mathrm{Et}_{2} \mathrm{NH}$ to remove the Fmoc group, and the resulting amine was coupled to either Fmoc-D-Alg-OH or Fmoc-D-Alg( $(\mathrm{Me})-\mathrm{OH}^{[16]}$ with BOP/DIPEA to obtain RCM-precursor peptides 32 and 33, respectively, in 74 to $75 \%$ yield. Both linear peptides were subjected to RCM in the presence of second generation Grubbs' catalyst. ${ }^{[19]}$ Peptide 32, which contained D-allylglycine (D-Alg), cyclized efficiently $(76 \%)$ to 34 in $5 \mathrm{~h}$ at $60^{\circ} \mathrm{C}$. However, peptide 33, which contained D-Alg( $(\beta \mathrm{Me})$, was difficult to cyclize-after $16 \mathrm{~h}$ in refluxing DCE 35 was obtained in only $29 \%$ yield. However, it should be emphasized that the presence of the $\beta$-methyl substituent was probably responsible for significant steric hindrance, which hampered ring-closure. Moreover, there are very few reports that describe successful ring-closure in the presence of such sterically hindered alkenes. ${ }^{[33]}$

The assembly of $\mathbf{2 9}$ with $\mathbf{3 4}$ into the $A B$ fragment mimic $\mathbf{4}$, and 29 with 35 into mimic 6 is depicted in Scheme 10. Peptide ester 29 was saponified with $\mathrm{LiOH}$ in $\mathrm{THF} / \mathrm{H}_{2} \mathrm{O}$, and peptide acid 36 was obtained in a quantitative yield. Fmoc-protected peptides $\mathbf{3 4}$ and $\mathbf{3 5}$ were treated with diethylamine to remove the Fmoc group. The resulting amines, $\mathbf{3 7}$ and 38, respectively, were subsequently coupled to 36 by the $\mathrm{EDCl} / \mathrm{HOBt}$ coupling method, as described above, to minimize racemization of the activated amino-acid residue. The protected bicyclic intermediates, 39 and 40, respectively, were used without further purification in the subsequent synthesis steps. These steps firstly involved saponification of the methyl ester ( $\mathrm{LiOH}$ in $\left.\mathrm{THF} / \mathrm{H}_{2} \mathrm{O}\right)$, and secondly, treatment with TFA in the presence of $\mathrm{TIS} / \mathrm{H}_{2} \mathrm{O}$ as scavengers to remove both Boc-protecting groups. After purification by HPLC, peptides 4 and 6 were obtained in 26 and $35 \%$ yield, respectively. Both peptides were analyzed and characterized by using LC-ES-MS, MALDI-TOF, and LC-MS/MS. In separate experiments, $A B$ fragment mimics 4 and $\mathbf{6}$ were reduced by $\mathrm{Pd} / \mathrm{H}_{2}$ to their corresponding alkane-bridged counterparts 5 and 7, respectively, in yields of $33 \%$.

\section{Biochemical evaluation}

The alkene- and alkane-bridged nisin $A B(C)$-fragment mimics 1-7 were tested for their lipid II binding affinities by evaluating their ability to inhibit nisin-induced carboxyfluorescein (CF) release from large unilamellar vesicles (LUVs). These vesicles contained DOPC and were loaded with lipid II (Figure 1).This assay was originally developed to investigate vancomycin and its derivatives for their affinity toward lipid II. ${ }^{[10 a]}$ Breukink and coworkers recently found that the mechanism of nisin-induced 


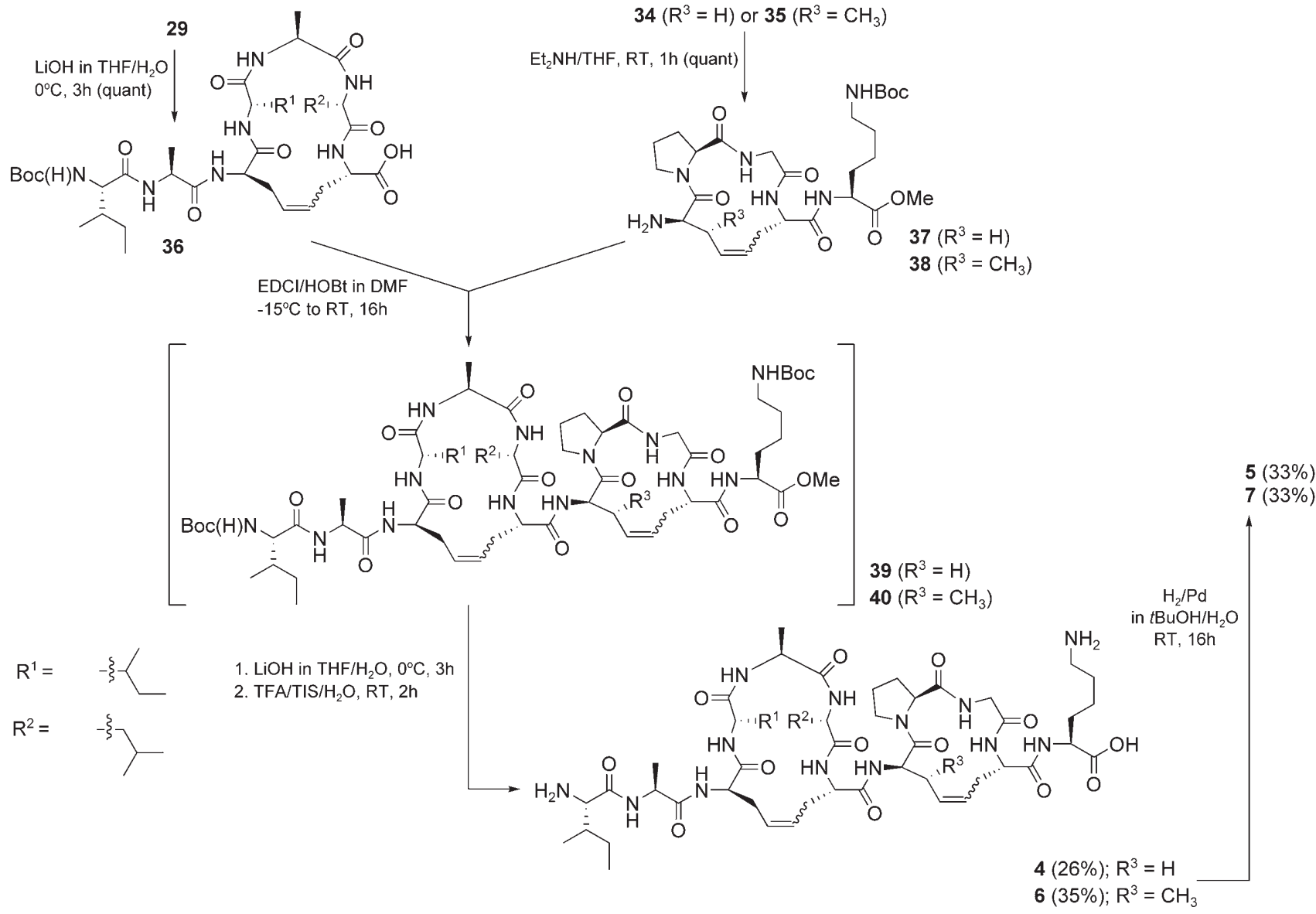

Scheme 10. Assembly of bicyclic peptides 4 and 6 from their respective monocyclic fragments.

pore formation is initiated by binding of the N-terminal $A B(C)$ fragment to lipid II. This enables the C-terminal DE fragment to interact with the phospholipid membrane and ultimately leads to pore formation and cell leakage. ${ }^{[34,35]}$ In the present study, the lipid II binding affinities of mimics 1-7 were evaluated and compared with those of the native $A B$ and $A B C$ fragments 41 and 42, respectively. The native $A B$ and $A B C$ fragments were obtained by trypsin and chymotrypsin digestion of nisin $A$, respectively, according to Chan et al. ${ }^{[36]}$

In a typical experiment, preincubation of CF-loaded DOPClipid II vesicles with $A B(C)$ fragments $1-7,41$, and 42 should result in the occupation of nisin-binding sites of lipid II. Depending on the affinity of the synthetic $A B(C)$ fragments toward lipid II, subsequent addition of full-length nisin will result in a reduced amount of pore formation and reduced fluorescence.

Nisin-induced pore formation was measured by the amount of CF release by using fluorescence spectroscopy, and was correlated to the maximum CF leakage, which was induced by the addition of Triton X-100. In a typical experiment, the synthetic $A B(C)$ fragment was added at $t=50 \mathrm{~s}$, and the fluorescence signal was measured at $t=70 \mathrm{~s}$. (The fluorescence was monitored continuously; however, the fluorescence values at the given time points were used for the calculations.) Nisin was added at $t=100 \mathrm{~s}$, and the increased fluorescence was measured at $t=140 \mathrm{~s}$. Finally, Triton X-100 was added at $t=$ $150 \mathrm{~s}$, and the end level of the fluorescence was determined at $t=190 \mathrm{~s}$. The leakage capacity was calculated by using the formula:

$\%$ CF leakage $=\frac{A_{t=140}-A_{t=70}}{A_{t=190}-A_{t=70}} \times 100$

Compared to Triton X-100, the maximum nisin-induced leakage percentage was found to be $73 \%$. The nisin-induced leakage percentages in the presence of the different $A B(C)$ fragments were correlated to this maximum value (Table 1). The time courses of the fluorescence signals of nisin-induced CF-leakage in the presence of $\mathbf{1 , 5}$, and $\mathbf{4 1}$ are given in Figure 1.

As expected, the natural $A B(C)$ fragments (41 and 42 ) as well as the synthetic $A B(C)$ fragment mimics (1-7) were not able to form pores in the phospholipid membrane since the $C$ terminal DE fragment of nisin, which is necessary for leakage, was absent. In the presence of these $A B(C)$ fragment mimics, nisin-induced carboxyfluorescein release was reduced; this indicated that these compounds were capable of competing with the nisin $A B C$-ring system for the pyrophosphate binding site. The natural $A B$ fragment $\mathbf{4 1}$ and the $A B(C)$ fragment $\mathbf{4 2}$ were found to be effective inhibitors of nisin-induced CF-leak- 


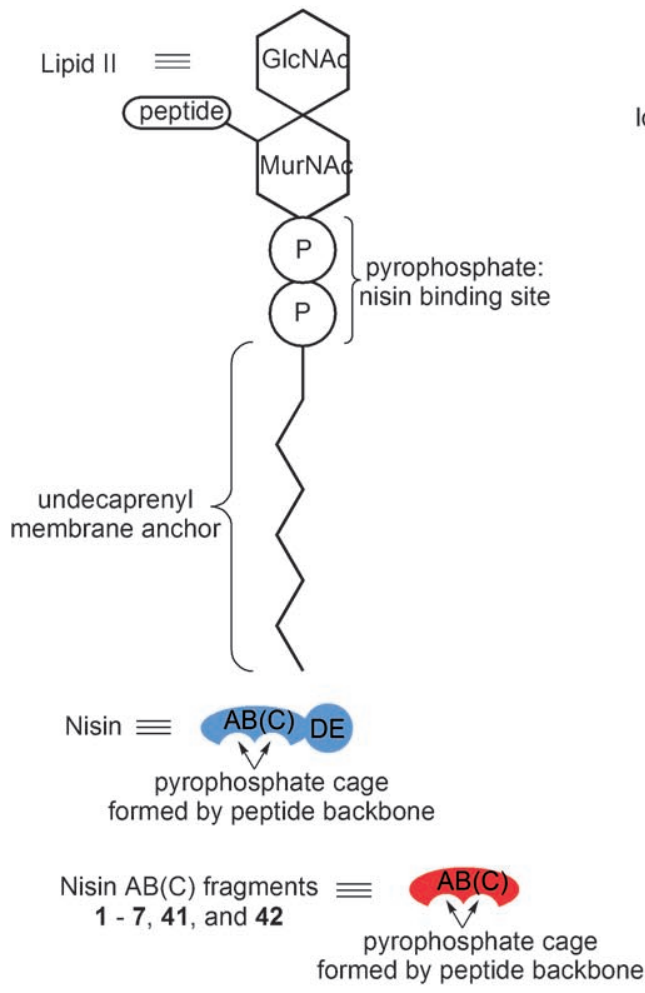

DOPC-lipid II vesicles (LUVs)

loaded with carboxyfluorescein (CF)
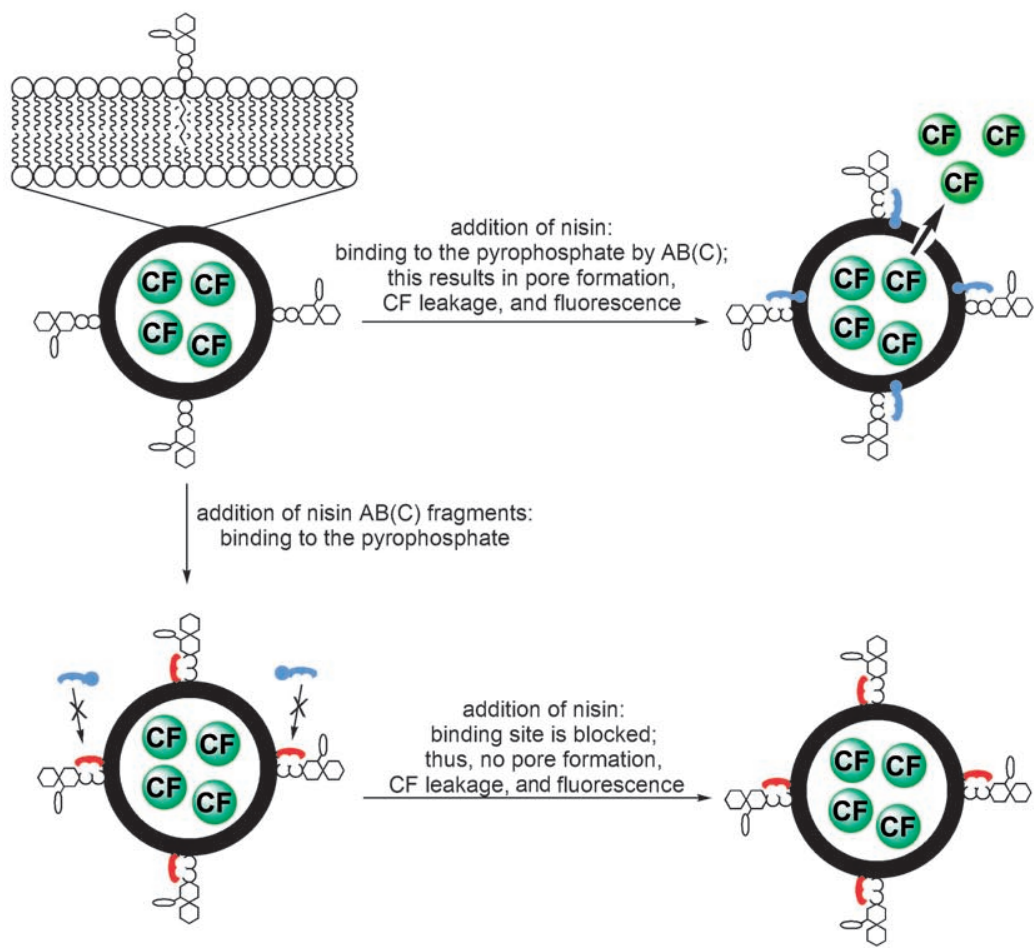

Figure 1. Schematic representation of the nisin-induced carboxyfluorescein (CF) release assay. Adapted from ref. [10a]; lipid II is shown only at the outer monolayer for clarity.

\begin{tabular}{|c|c|c|c|c|}
\hline & Compound & Conc. $[\mu \mathrm{M}]$ & $\begin{array}{l}\text { Nisin-induced } \\
\text { CF leakage [\%] }\end{array}$ & $\begin{array}{l}\text { Inhibition of } \\
\text { CF leakage [\%] }\end{array}$ \\
\hline 1 & 1 & 50 & 96 & 4 \\
\hline 2 & 1 & 100 & 77 & 23 \\
\hline 3 & 2 & 50 & 100 & 0 \\
\hline 4 & 2 & 100 & 86 & 14 \\
\hline 5 & 2 & 200 & 66 & 34 \\
\hline 6 & 3 & 50 & 79 & 21 \\
\hline 7 & 3 & 100 & 64 & 36 \\
\hline 8 & 4 & 50 & 90 & 10 \\
\hline 9 & 4 & 100 & 92 & 8 \\
\hline 10 & 4 & 200 & 86 & 14 \\
\hline 11 & 4 & 400 & 27 & 73 \\
\hline 12 & 5 & 25 & 100 & 0 \\
\hline 13 & 5 & 50 & 78 & 22 \\
\hline 14 & 5 & 100 & 56 & 44 \\
\hline 15 & 6 & 50 & 99 & 1 \\
\hline 16 & 6 & 100 & 100 & 0 \\
\hline 17 & 6 & 200 & 96 & 4 \\
\hline 18 & 7 & 50 & 100 & 0 \\
\hline 19 & 7 & 200 & 100 & 0 \\
\hline 20 & 41 & 10 & 86 & 14 \\
\hline 21 & 41 & 20 & 63 & 37 \\
\hline 22 & 41 & 28 & 41 & 59 \\
\hline 23 & 41 & 40 & 18 & 72 \\
\hline 24 & 42 & 0.2 & 100 & 0 \\
\hline 25 & 42 & 1 & 93 & 7 \\
\hline 26 & 42 & 2.5 & 52 & 48 \\
\hline 27 & 42 & 25 & 6 & 93 \\
\hline
\end{tabular}

age, and were active in the low $\mu \mathrm{M}$ range (Table 1 and Figure 2).

Generally, the alkene- and alkane-bridged nisin $A B(C)$-mimics were found to be less active than their natural counterparts. However, subtle variations in activity were observed. The alkane-bridged derivatives showed at least a comparable activity, but were generally more active than their alkene-bridged congeners (compare entries 9 and 14 in Table 1). Also, the alkene-bridge $A B C$-ring fragment $\mathbf{3}$ was more active than the AB-ring mimic 1 (compare entries 2 and 7). Moreover, a clear improvement of lipid II-binding affinity was observed with these mimics when there was an identical stereochemistry to the native nisin fragments (compare entries 4 and 14). Remarkably, compounds 6 and 7, which had an even closer resemblance to nisin, and had the 3-methyllanthionine mimic, were completely inactive in this assay. The highest affinity towards lipid II was found with the alkane-bridged compound 5 . These binding data imply that an alkane moiety is a suitable sulfidebridge (thioether) mimic, and that compounds with the same backbone stereochemistry as nisin are considerably more active.

\section{Computational modeling}

Modeling studies on 1, 2, 4-7, and 41 were performed with MacroModel ${ }^{[37]}$ in order to find the energy and structure of the global minimum. To obtain the global minimum, conforma- 

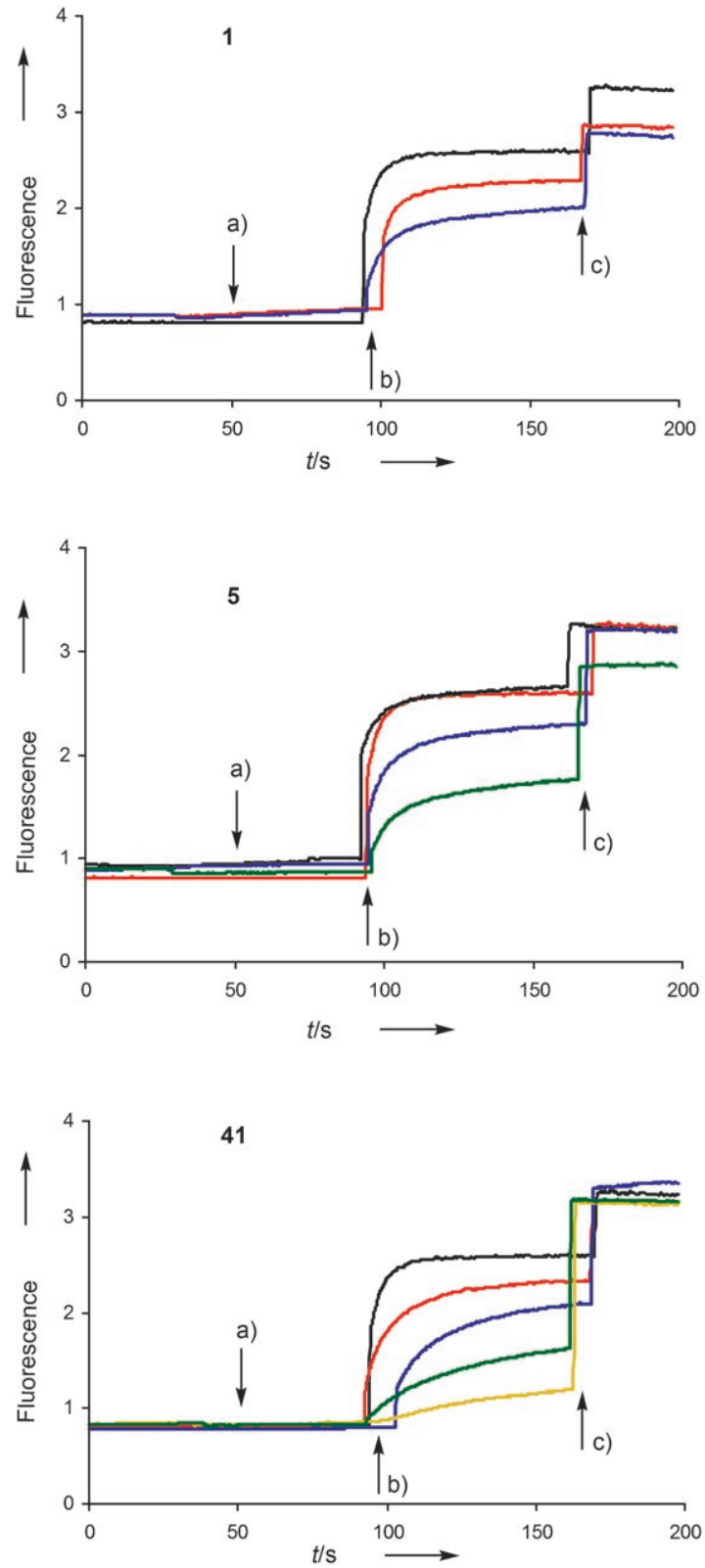

Figure 2. Time course of nisin-induced leakage of carboxyfluorescein (CF) from DOPC vesicles with lipid II (black line). After $100 \mathrm{~s}$ (b), full-length nisin was added and CF release was monitored. The $100 \%$ leakage level was determined by addition of Triton X-100 after $\sim 180 \mathrm{~s}$ (c). At $\mathrm{t} \sim 50 \mathrm{~s}$ (a), a nisin $A B(C)$ fragment $(\mathbf{1}, \mathbf{5}$, or $\mathbf{4 1})$ was added as potential lipid II binder; this resulted in reduced CF efflux and thus lower fluorescence signals. The red, blue, green, and yellow traces indicate the increasing concentration of the $\mathrm{AB}(\mathrm{C})$ fragments: 1 (50 and $100 \mu \mathrm{M}$, respectively); 5 (25, 50, and $100 \mu \mathrm{M}$, respectively); 41 (10, 20, 28, and $40 \mu \mathrm{M}$, respectively).

tional searches were performed with $\mathrm{H}_{2} \mathrm{O}$ as solvent since the binding studies were performed in aqueous solution. From each structure the molecular mechanics energy $\left(\mathrm{kJ} \mathrm{mol}^{-1}\right)$ of the global minimum was calculated with $E, E, E, Z, Z, E$, and $Z, Z$ geometries of the double bond (Table 2).

For compound 1 (all-L stereochemistry of the peptide backbone) the order of molecular mechanics energy value was: $Z, E \ll Z, Z \approx E, Z \ll E, E$. In the case of 4 , which had the same backbone stereochemistry as nisin, the order was found to be:

\begin{tabular}{|c|c|c|c|}
\hline Compound $^{[a]}$ & $\begin{array}{c}\text { Double-bond } \\
\text { geometry }\end{array}$ & Energy $\left[\mathrm{kJ} \mathrm{mol}^{-1}\right]$ & $\operatorname{RMS}[\AA]]^{[b]}$ \\
\hline 1 & $E, E$ & 286.6 & - \\
\hline 1 & $E, Z$ & 279.4 & - \\
\hline 1 & $Z, E$ & 268.1 & 2.24 \\
\hline 1 & $Z, Z$ & 278.9 & - \\
\hline 2 & - & 153.7 & 1.11 \\
\hline 4 & $E, E$ & 316.1 & - \\
\hline 4 & $E, Z$ & 315.2 & - \\
\hline 4 & $Z, E$ & 318.6 & - \\
\hline 4 & $Z, Z$ & 308.1 & 1.64 \\
\hline 5 & - & 130.4 & 1.73 \\
\hline 6 & $E, E$ & 332.6 & 1.26 \\
\hline 6 & $E, Z$ & 332.0 & - \\
\hline 6 & $Z, E$ & 339.8 & - \\
\hline 6 & $Z, Z$ & 337.9 & - \\
\hline 7 & - & 157.8 & 1.54 \\
\hline nisin $A B(41)$ & - & 372.5 & - \\
\hline \multicolumn{4}{|c|}{$\begin{array}{l}\text { [a] } N \text {-acetylated and NHMe-amidated bicyclic compounds were used in } \\
\text { the modeling experiments. [b] RMS values were calculated based on the } \\
\text { superimposition of carbon atoms } \alpha C 1, \alpha C 5, \alpha C 6 \text {, and } \alpha C 9 \text { onto } \mathbf{1}, \mathbf{2}, \mathbf{4}, \mathbf{5} \text {, } \\
\mathbf{6 , 7}, \mathbf{7} \text { and native nisin } \mathrm{AB}(\mathbf{4 1}) \text {. }\end{array}$} \\
\hline
\end{tabular}

$Z, Z \ll E, Z \approx E, E<Z, E$. However, the absolute value of the molecular mechanics energy was significantly lower for $\mathbf{1}$ than for $\mathbf{4}$. This is in contrast to the alkane series for which the energy of 5 (derived from alkene 4) was found to be much lower than 2 (derived from 1).

Superimposed images of the lowest energy conformers of $\mathbf{2}$ or 5 and native nisin $A B(\mathbf{4 1})$ are shown in Figure 3. The root mean square (RMS) values were calculated based on the superimposition of carbon atoms $\alpha \mathrm{C} 1, \alpha \mathrm{C} 5, \alpha \mathrm{C} 6$, and $\alpha \mathrm{C} 9$ in these derivatives with native nisin $A B$ (Table 2). As can be seen from Figure 3 the superimposition of the $A$ ring is quite good compared to the $B$ ring, which can be explained by the fact that each ring fragment can rotate independently. In this case, the lowest RMS value $(1.1 \AA)$ was observed with the dialkanebridged compound 2. Based on these modeling data, it was not possible to draw any conclusions, or to observe a correlation with respect to the measured lipid II binding affinities.

\section{Conclusions}

A series of alkene- and alkane-bridged $A B(C)$-ring fragments of the lantibiotic nisin were synthesized by ring-closing metathesis, to mimic the natural thioether covalent constraint. These compounds were tested for their binding affinities toward lipid II, and depending on the stereochemistry of the peptide backbone, were found to be active, although with a reduced affinity compared to their natural counterparts. The most active compound, 5, resembled the native backbone stereochemistry, but the thioether was mimicked by an alkane bridge. These compounds comprise a first generation lead set for the design of novel peptide-based antibiotics based on nisin. 


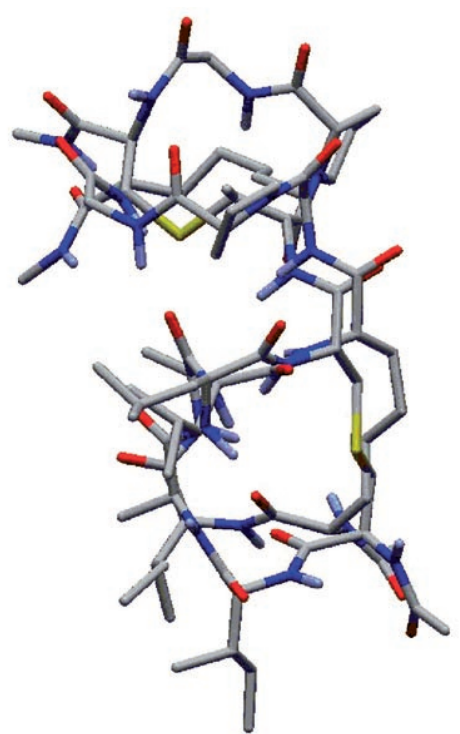

2/native $A B$

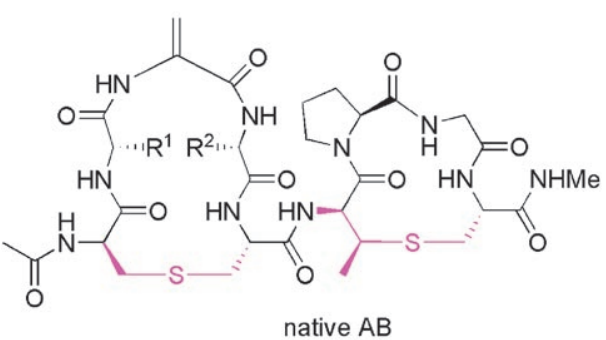

$\mathrm{R}^{1}=$

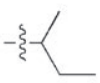

$\mathrm{R}^{2}=$

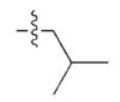

Figure 3. Superimposed images of the lowest energy conformations of $\mathbf{2}$ and $\mathbf{5}$ with native nisin $A B$ fragment.

\section{Experimental Section}

General: Analytical HPLC was performed by using a Shimadzu automated HPLC system equipped with an evaporative light scattering detector (PL-ELS 1000, Polymer Laboratories) and a UV/Vis detector operated at 220/254 nm. Preparative HPLC was performed by using a Gilson HPLC workstation. Liquid chromatography electrospray ionization mass spectrometry (ES-MS) was measured by using a Shimadzu LCMS-QP8000 single quadrupole bench-top mass spectrometer, which was operated in the positive-ionization mode. MALDI-TOF analysis was performed by using a Kratos Axima CFR apparatus, with bradykinin(1-7) as an external reference and $\alpha$-cyano-4-hydroxycinnamic acid as matrix. MS/MS spectra were analyzed by using a Micromass Quattro Ultima or a Micromass Q-TOF mass spectrometer. ${ }^{1} \mathrm{H}$ NMR spectra were recorded by using a Varian G-300 (300 MHz) spectrometer or a Varian INOVA-500 spectrometer $(500 \mathrm{MHz})$; chemical shifts $(\delta)$ were obtained in ppm relative to TMS. ${ }^{13} \mathrm{C}$ NMR spectra were recorded on a Varian G-300 spectrometer $(75.5 \mathrm{MHz})$ and the chemical shifts were obtained in ppm relative to $\mathrm{CDCl}_{3}(77.0 \mathrm{ppm})$. The ${ }^{13} \mathrm{C}$ NMR spectra were recorded by using the attached proton test (APT) sequence. Retention factor $\left(R_{\mathrm{f}}\right)$ values were determined with thin-layer chromatography (TLC) by using Merck precoated silica gel $60 \mathrm{~F}_{254}$ plates. Spots were visualized by UV-quenching, ninhydrin, or $\mathrm{Cl}_{2} / N, N, N^{\prime}, N^{\prime}$-tetramethyl-4,4'-diaminodiphenylmethane (TDM). ${ }^{[38]}$ The numbering of the amino acids listed in the NMR characterizations are given from the $\mathrm{N}$ to $\mathrm{C}$ terminus. Where appropriate, this numbering is indicated as superscripts in the compound name for clarity.
Chemicals and reagents: Argo$\mathrm{Gel}^{\mathrm{TM}}$ resin with a free hydroxyl moiety was used in all synthesis procedures. The coupling reagents 2-(1H-benzotriazol-1-yl)-1,1,3,3-tetramethyluronium hexafluorophosphate (HBTU) ${ }^{[39]}$ and benzotriazol1-yl-oxy-tris-(dimethylamino)phosphonium hexafluorophosphate

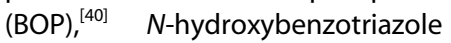
(HOBt), and $N^{\alpha}$-9-fluorenylmethyloxycarbonyl (Fmoc) amino acids were obtained from GL Biochem Ltd. (Shanghai, China). The Fmocprotected L- and D-allylglycine (Alg) were purchased from Neosystem Laboratoire (Strasbourg, France). Peptide grade 1,2-dichloroethane (DCE), dichloromethane (DCM), N,N-dimethylformamide (DMF), tert-butyl methylether (MTBE), trifluoroacetic acid (TFA), and HPLC grade acetronitrile were purchased from Biosolve (Valkenswaard, The Netherlands). Piperidine, $\quad \mathrm{N}, \mathrm{N}$-diisopropylethylamine (DIPEA) and 4-dimethylaminopyridine (DMAP) were obtained from Acros Organics (Geel, Belgium). Triisopropylsilane (TIS) and HPLC grade TFA were obtained from Merck. $\quad N$-ethyl- $N$ '-(3-dimethylaminopropyl)carbodiimide (EDCI) and second generation Grubbs' catalyst $\left(\mathrm{Ru} \mathrm{u}^{\mathrm{Il}}\right)$ were obtained from $\mathrm{Al}$ drich. Nisin A, trypsin, and chymotrypsin were obtained from Sigma.

Solid-phase peptide synthesis: Peptides were synthesized manually at the $0.25 \mathrm{mmol}$ scale on Argogel resin. Each synthetic cycle consisted of $N^{\alpha}$-Fmoc removal by treatment with piperidine (20\%) in DMF $(3 \times 10 \mathrm{~mL}, 8 \mathrm{~min})$, a wash step (DMF: $3 \times 10 \mathrm{~mL}, 2 \mathrm{~min}$; DCM: $3 \times 10 \mathrm{~mL}, 2 \mathrm{~min}$; and DMF: $3 \times 10 \mathrm{~mL}, 2 \mathrm{~min})$, a coupling step $(60 \mathrm{~min}, 1.0 \mathrm{mmol}$ of preactivated Fmoc amino acid in the presence of 2 equiv DIPEA in $10 \mathrm{~mL}$ DMF), and a final wash step (DMF: $3 \times 10 \mathrm{~mL}, 2 \mathrm{~min}$; DCM: $3 \times 10 \mathrm{~mL}, 2 \mathrm{~min}$; and DMF: $3 \times$ $10 \mathrm{~mL}, 2 \mathrm{~min}) . N^{\alpha}-\mathrm{Fmoc}$ amino acids $(1 \mathrm{mmol})$ were activated in situ with BOP $(1 \mathrm{mmol})$ in the presence of DIPEA ( $2 \mathrm{mmol})$. Fmocremoval and-coupling reactions were monitored by using the Kaiser test. ${ }^{[41]}$ Peptides were cleaved from the resin by treatment with a catalytic amount of $\mathrm{KCN}$ in $\mathrm{MeOH}(15 \mathrm{~mL})$ for $16 \mathrm{~h}$. The resin was filtered and washed with $\mathrm{MeOH}(3 \times 10 \mathrm{~mL})$, and the filtrate was concentrated in vacuo to yield the crude peptide.

\section{Solution-phase peptide synthesis}

Coupling reaction: The carboxylic acid moiety (1 equiv) was coupled to the amine derivative (or its TFA salt, 1 equiv) in the presence of BOP ( 1 equiv) and DIPEA ( 2 equiv; 3 equiv when the amine was protonated) as coupling reagents in DCM $\left(10 \mathrm{~mL} \mathrm{mmol}^{-1}\right)$ as solvent ( $16 \mathrm{~h}$, room temperature). After completion of the reaction, DCM was removed under reduced pressure, and the residue was dissolved in EtOAc $\left(25 \mathrm{~mL} \mathrm{mmol}^{-1}\right)$. The solution was washed with $\mathrm{KHSO}_{4}(1 \mathrm{~N}, 3 \times 25 \mathrm{~mL}), 10 \% \mathrm{Na}_{2} \mathrm{CO}_{3}(3 \times 25 \mathrm{~mL})$, and brine $(1 \times$ $25 \mathrm{~mL})$, then dried $\left(\mathrm{Na}_{2} \mathrm{SO}_{4}\right)$, filtrated, and evaporated in vacuo. The 
obtained crude product was analyzed by TLC, ${ }^{1} \mathrm{H}$ NMR spectroscopy, and ESI-MS, and in general proved pure enough to be used in subsequent synthesis steps.

Boc removal: A Boc-protected intermediate was dissolved in TFA/ $\operatorname{DCM}\left(1: 1, v / v ; 4 \mathrm{~mL} \mathrm{mmol}^{-1}\right)$ and stirred at room temperature for $1 \mathrm{~h}$. Then the solvents were removed under reduced pressure and the residue was coevaporated with toluene $(2 \times 25 \mathrm{~mL}), \mathrm{CH}_{3} \mathrm{CN}(2 \times$ $25 \mathrm{~mL})$, and DCM $(2 \times 25 \mathrm{~mL})$ to remove residual TFA. The obtained TFA salt was used without further purification in the next synthesis step.

Peptide purification: The crude lyophilized peptides $(30-60 \mathrm{mg}$ ) were dissolved in a minimum amount of TFA $(0.1 \%)$ in $\mathrm{CH}_{3} \mathrm{CN} / \mathrm{H}_{2} \mathrm{O}$ $(8: 2, v / v)$ and loaded onto an Adsorbosphere XL C8 HPLC column ( $90 \AA$ pore size, $10 \mu \mathrm{m}$ particle size, $2.2 \times 25 \mathrm{~cm}$ ). The peptides were eluted at a $10.0 \mathrm{~mL} \mathrm{~min}{ }^{-1}$ over $60 \mathrm{~min}$ by using a linear gradient from $100 \%$ buffer $\mathrm{A}\left(0.1 \%\right.$ TFA in $\left.\mathrm{H}_{2} \mathrm{O}\right)$ to $100 \%$ buffer $\mathrm{B}(0.1 \%$ TFA in $\left.\mathrm{CH}_{3} \mathrm{CN} / \mathrm{H}_{2} \mathrm{O} 95: 5, \mathrm{v} / \mathrm{v}\right)$. The peptide purity and retention time $\left(t_{\mathrm{R}}\right)$ values were evaluated with analytical HPLC by using an Adsorbosphere XL C8 column (90 $\AA$ pore size, $5 \mu \mathrm{m}$ particle size, $0.46 \times$ $25 \mathrm{~cm}$ ) at $1 \mathrm{~mL} \mathrm{~min}{ }^{-1}$ over 30 min by using a linear gradient of buffers $A$ and $B$ as above.

Peptide characterization: Peptides were characterized by mass spectrometry and ${ }^{1} \mathrm{H}$ NMR spectroscopy (300 or $500 \mathrm{MHz}$ ). The mass of each analogue was measured, and the observed monoisotopic $[\mathrm{M}+\mathrm{H}]^{+}$values were correlated with the calculated $[\mathrm{M}+\mathrm{H}]^{+}$ values by using MacBioSpec (Perkin-Elmer Sciex Instruments, Thornhill, Ontario, Canada). Peak assignments were based on ${ }^{1} \mathrm{H}$ NMR COSY, TOCSY, and/or ROESY spectra.

Synthesis: Experimental details of all synthetic procedures and characterization data of all intermediate compounds are described in the Supporting Information.

2 TFA.H-IIe $-A l a^{2}-$ cyclo[Alg ${ }^{3}-I l e^{4}-A l a^{5}-$ Leu $^{6}-$ Alg $\left.^{7}\right]$-cyclo $\left[A l g^{8}-\right.$ Pro ${ }^{9}-G l y^{10}$ -

$\left.A l g^{11}\right]-$ Lys $^{12}-\mathrm{OH}$ (1): $t_{\mathrm{R}}: 14.2 \mathrm{~min}$; ESMS: calcd for $\mathrm{C}_{53} \mathrm{H}_{88} \mathrm{~N}_{13} \mathrm{O}_{13}$ : 1114.70, found: $\mathrm{m} / \mathrm{z} \quad[\mathrm{M}+\mathrm{H}]^{+}$ 1114.75; MALDI-TOF: $[\mathrm{M}+\mathrm{H}]^{+}$ 1114.97, $[\mathrm{M}+\mathrm{Na}]^{+}$1136.92; MS/MS analysis:

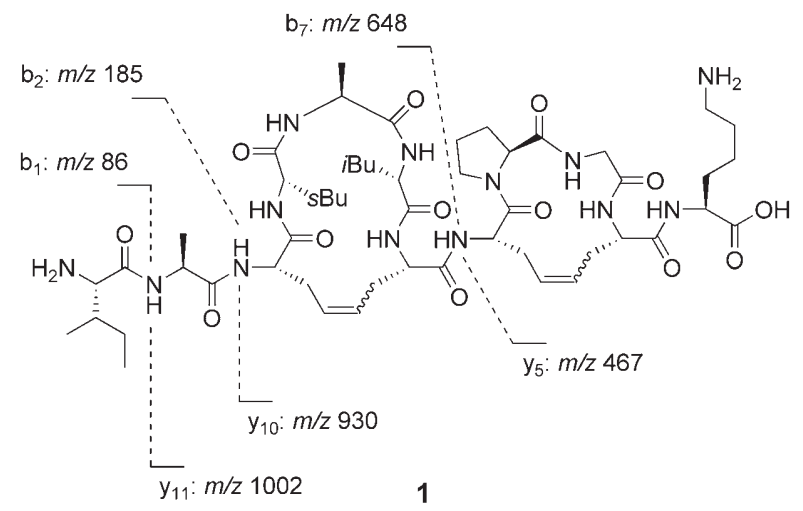

Bicyclic alkane-bridged compound 2: $t_{\mathrm{R}}: 14.7 \mathrm{~min}$; ES-MS: calcd for $\mathrm{C}_{53} \mathrm{H}_{92} \mathrm{~N}_{13} \mathrm{O}_{13}$ : 1118.70, found: $\mathrm{m} / \mathrm{z}[\mathrm{M}+\mathrm{H}]^{+}$1118.8, $[M+2 \mathrm{H}]^{2+} 560.1$; MALDI-TOF: $[M+\mathrm{H}]^{+}$1119.0, $[\mathrm{M}+\mathrm{Na}]^{+}$1141.0; MS/MS analysis:

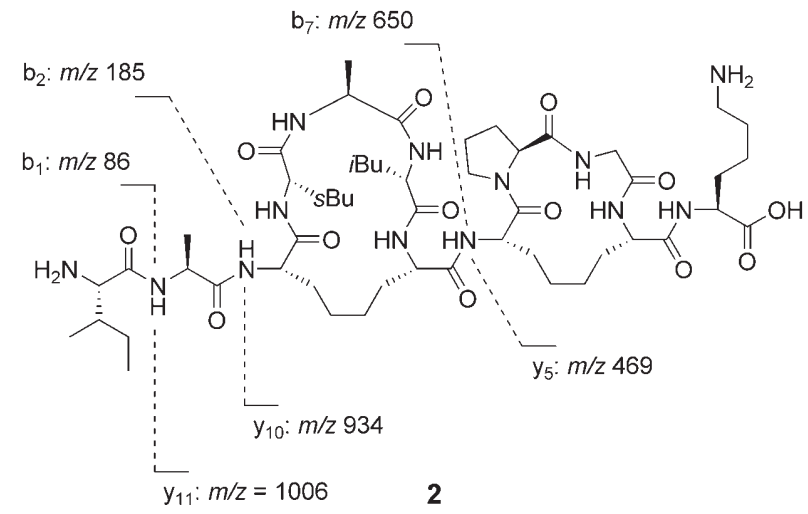

$2 H C l \cdot H-I l e^{1}-A l a^{2}-$ cyclo $\left[A l g^{3}-I l e^{4}-A l a^{5}-L e u^{6}-A l g^{7}\right]-c y c l o\left[A l g^{8}-P r O^{9}-G l y^{10}-\right.$

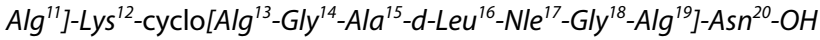
(3): $t_{R}: 14.7$ min; ES-MS: calcd for $\mathrm{C}_{84} \mathrm{H}_{137} \mathrm{~N}_{22} \mathrm{O}_{22}: 1807.1$, found: $\mathrm{m} / \mathrm{z}$ MALDI-TOF: $[\mathrm{M}+\mathrm{H}]^{+}$1807.13, $[\mathrm{M}+\mathrm{Na}]^{+}$1829.1; MS/MS analysis:

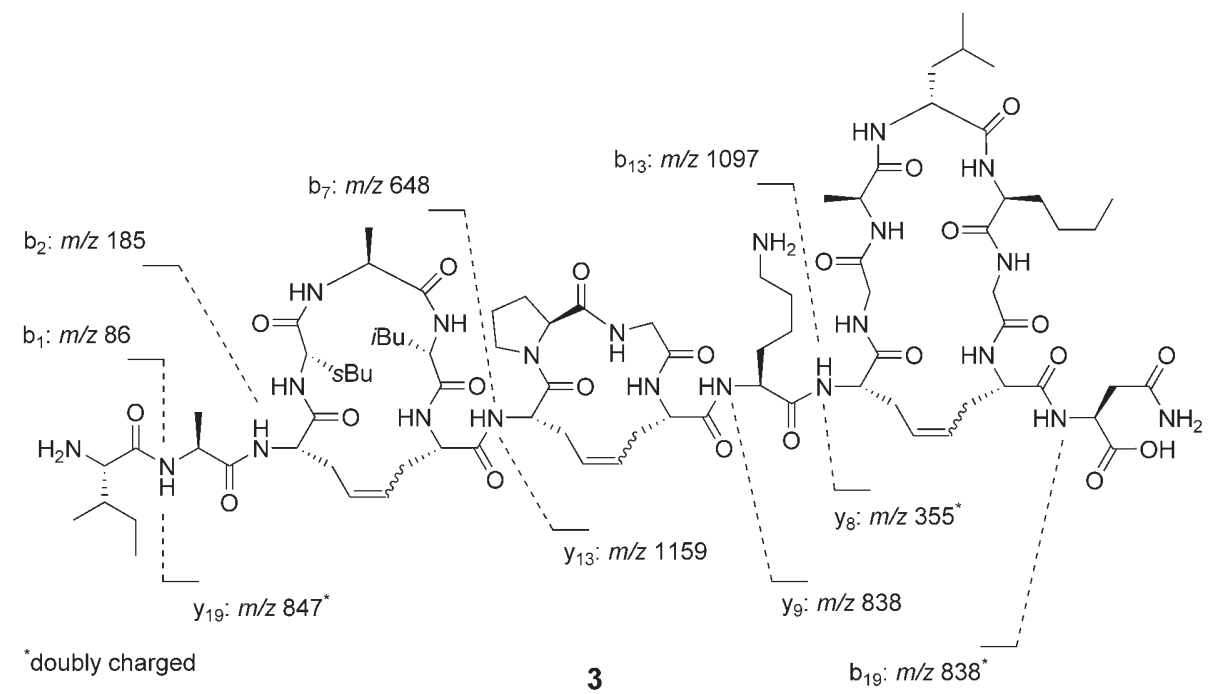

2 TFA $\cdot H-I l e^{1}-A l a^{2}-$ cyclo $\left[D-A l g^{3}-I l e^{4}-A l a^{5}-L e u^{6}-A l g^{7}\right]-\mathrm{cyclo}\left[D-A l g^{8}-P r O^{9}-\right.$ Gly ${ }^{10}-A^{\prime 1} g^{11}$ J-Lys ${ }^{12}-\mathrm{OH}$ (4): $t_{\mathrm{R}}$ : $14.2 \mathrm{~min}$; ES-MS: calcd for $\mathrm{C}_{53} \mathrm{H}_{88} \mathrm{~N}_{13} \mathrm{O}_{13}$ : 1114.70, found: $\mathrm{m} / \mathrm{z}[\mathrm{M}+\mathrm{H}]^{+}$1115.25, $[\mathrm{M}+2 \mathrm{H}]^{2+}$ 558.33; MALDITOF: $[M+\mathrm{H}]^{+}$1114.65, $[\mathrm{M}+\mathrm{Na}]^{+}$1136.58; MS/MS analysis:

Bicyclic alkane-bridged compound 5: $t_{\mathrm{R}}: 16.2 \mathrm{~min}$; ES-MS: calcd for $\mathrm{C}_{53} \mathrm{H}_{92} \mathrm{~N}_{13} \mathrm{O}_{13}:$ 1118.70, found: $\mathrm{m} / \mathrm{z}[\mathrm{M}+\mathrm{H}]^{+}$1118.90, $[M+2 \mathrm{H}]^{2+}$ 560.40; MALDI-TOF: $[\mathrm{M}+\mathrm{H}]^{+}$1118.6, $[\mathrm{M}+\mathrm{Na}]^{+}$1140.5; MS/MS analysis:

2 TFA.H-Ile $-A l a^{2}-$ cyclo[D-Alg $\left.-I l e^{4}-A l a^{5}-L e u^{6}-A l g^{7}\right]$-cyclo[D-Alg $(\beta M e)^{8}-$ Pro $\left.{ }^{9}-G_{1}{ }^{10}-\mathrm{Alg}^{11}\right]-\mathrm{Lys}^{12}-\mathrm{OH}$ (6): $t_{\mathrm{R}}: 17.8 \mathrm{~min}$; ES-MS: calcd for $\mathrm{C}_{54} \mathrm{H}_{90} \mathrm{~N}_{13} \mathrm{O}_{13}:$ 1128.67, found: $\mathrm{m} / \mathrm{z}[\mathrm{M}+\mathrm{H}]^{+} 1128.95,[\mathrm{M}+2 \mathrm{H}]^{2+}$ 565.35; MALDI-TOF: $[M+\mathrm{H}]^{+}$1128.89, $[\mathrm{M}+\mathrm{Na}]^{+}$1150.85; $[\mathrm{M}+\mathrm{K}]^{+}$ 1166.81; MS/MS analysis:

Bicyclic alkane-bridged compound 7: $t_{\mathrm{R}}: 12.8 \mathrm{~min}$; ES-MS: calcd for $\mathrm{C}_{54} \mathrm{H}_{94} \mathrm{~N}_{13} \mathrm{O}_{13}:$ 1132.67, found: $\mathrm{m} / \mathrm{z}[\mathrm{M}+\mathrm{H}]^{+}$1132.70, $[M+2 \mathrm{H}]^{2+}$ 

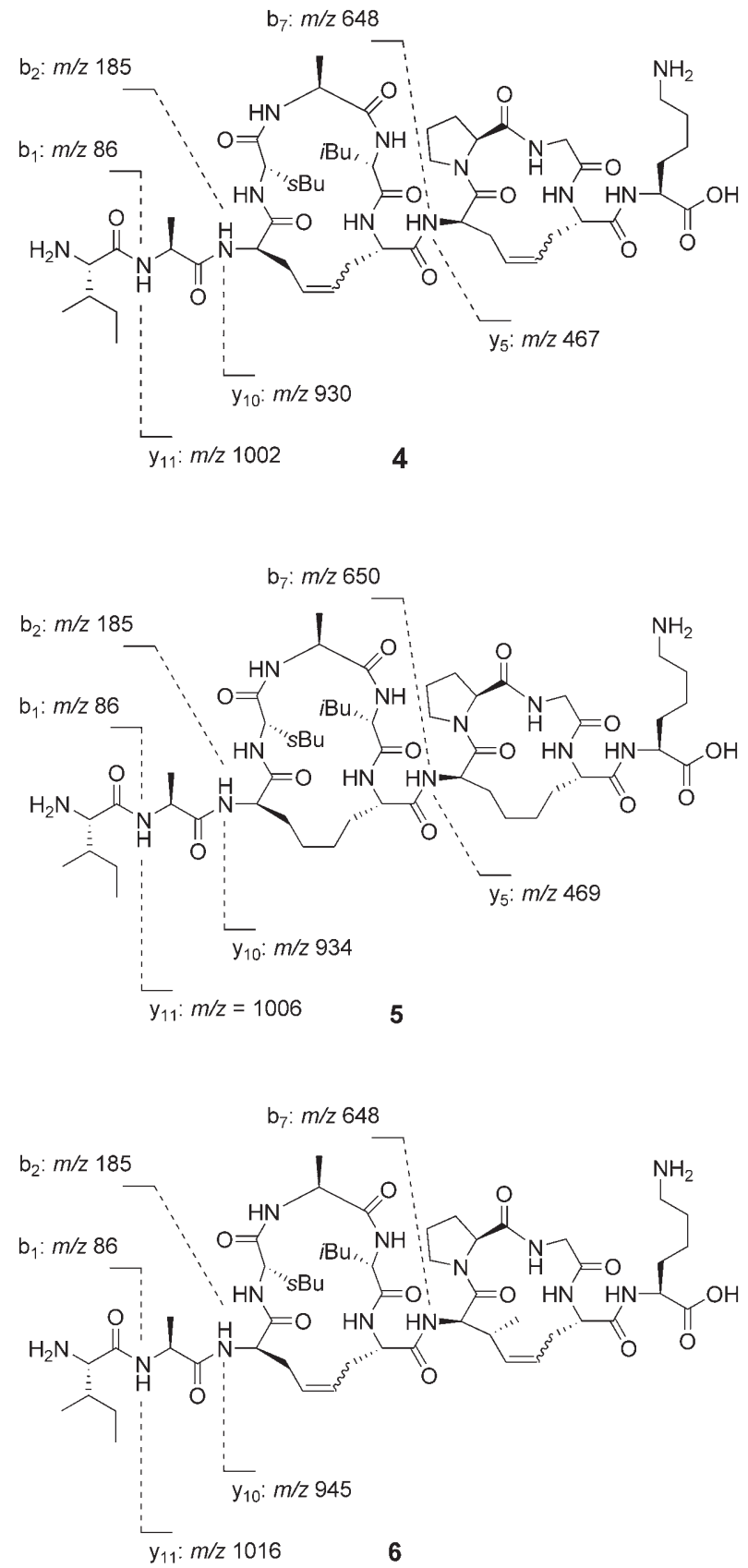

567.5; MALDI-TOF: $[M+\mathrm{H}]^{+}$1132.80, $[\mathrm{M}+\mathrm{Na}]^{+} 1154.70 ;[\mathrm{M}+\mathrm{K}]^{+}$ 1170.70; MS/MS analysis:

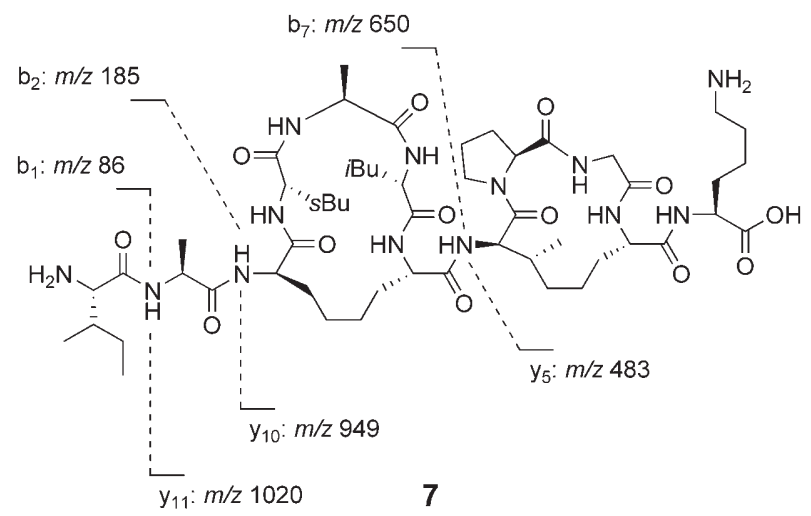

Biological evaluation: The method described by Wiedemann et al. was used. ${ }^{[10 a]}$ Briefly, large unilamellar vesicles (LUVs) for carboxyfluorescein (CF) efflux were prepared and treated as described by Breukink et al. ${ }^{[3 a]}$ Vesicles were made from 1,2-dioleoyl-sn-glycero3-phosphatidylcholine (DOPC) which contained lipid II (0.1\%). CFloaded vesicles were prepared with CF $(50 \mathrm{~mm})$ and then diluted in $\mathrm{K}^{+}$buffer $(1.5 \mathrm{~mL}$, containing $25 \mathrm{~mm}$ 4-morpholineethanesulfonic acid (MES)-KOH, $\mathrm{pH} 6.0,75 \mathrm{mM} \mathrm{K}_{2} \mathrm{SO}_{4}$ ) at a final phospholipid concentration of $25 \mu \mathrm{M}$. After the addition of nisin, induced leakage was monitored for $3 \mathrm{~min}$. The increase of fluorescence was measured at $515 \mathrm{~nm}$ (excitation at $492 \mathrm{~nm}$ ) by using a SPF 500C spectrophotometer (SLM Instruments Inc.) at $20^{\circ} \mathrm{C}$. The nisin-induced CF leakage was expressed relative to the total amount of CF released after lysis of the vesicles by addition of Triton X-100 (20\%, $10 \mu \mathrm{L})$.

Lipid II-binding affinity of the different $A B(C)$ fragments 1-7, 41, and 42 was assayed by measuring the reduced induction of CF leakage in response to nisin $(8 \mathrm{~nm})$. The compounds were preincubated with CF-loaded vesicles for $50 \mathrm{~s}$. None of the tested compounds induced CF leakage during this preincubation period. Then nisin was added, and an immediate increase in absorption was observed in cases where the $A B(C)$ fragment did not bind lipid II. A reduced fluorescence signal as function of concentration was observed in cases where the $A B(C)$ fragments showed an affinity toward lipid II. Finally, treatment with Triton X-100 induced total CF release; this value was used to calculate the relative potency of the $A B(C)$ fragments to binding lipid II.

\section{Acknowledgements}

We thank Dr. Johan Kemmink for his assistance in measuring the $500 \mathrm{MHz}{ }^{1} \mathrm{H}$ NMR spectra, and Cees Versluis is acknowledged for performing the MS/MS experiments.

Keywords: antibiotics - bioorganic chemistry - medicinal chemistry - membrane-peptide interactions • ring-closing metathesis

[1] a) G. Jung, Angew. Chem. 1991, 103, 1067-1085; Angew. Chem. Int. Ed. Engl. 1991, 30, 1051-1068; b) C. Chatterjee, M. Paul, L. Xie, W. A. van der Donk, Chem. Rev. 2005, 105, 633-683.

[2] E. Gross, J. L. Morell, J. Am. Chem. Soc. 1971, 93, 4634-4635.

[3] a) E. Breukink, C. van Kraaij, R. A. Demel, R. J. Siezen, O. P. Kuipers, B. de Kruijff, Biochemistry 1997, 36, 6968-6976; b) C. van Kraaij, E. Breukink, M. A. Noordermeer, R. A. Demel, R. J. Siezen, O. P. Kuipers, B. de Kruijff, Biochemistry 1998, 37, 16033-16044; c) E. Breukink, I. Wiedemann, C. van Kraaij, O.P. Kuipers, H.-G. Sahl, B. de Kruijff, Science 1999, 286, $2361-2364$; d) E. Breukink, H. E. van Heusden, P. J. Vollmerhaus, E. Swiezewska, L. Brunner, S. Walker, A. J. R. Heck, B. de Kruijff, J. Biol. Chem. 2003, 278, 19898-19903.

[4] The first total synthesis of lipid II: M. S. VanNieuwenhze, S. C. Mauldin, M. Zia-Ebrahimi, B. E. Winger, W. J. Hornback, S. L. Saha, J. A. Aikins, L. C. Blaszczak, J. Am. Chem. Soc. 2002, 124, 3656-3660.

[5] a) J. van Heijenoort in Bacterial Cell Wall (Eds.: J.-M. Ghuysen, R. Hakenbeek), Elsevier, Amsterdam, 1994, Vol. 27, pp. 39-54; b) J. van Heijenoort, Glycobiology 2001, 11, 25R-36R.

[6] a) D. H. Williams, B. Bardsley, Angew. Chem. 1999, 111, 1264-1286; Angew. Chem. Int. Ed. 1999, 38, 1172-1193; b) K. C. Nicolaou, C. N. C. Boddy, S. Bräse, N. Winssinger, Angew. Chem. 1999, 111, 2230-2287; Angew. Chem. Int. Ed. 1999, 38, 2096-2152; c) T. D. H. Bugg, C. T. Walsh, Nat. Prod. Rep. 1992, 9, 199-215.

[7] a) H. Brötz, M. Josten, I. Wiedemann, U. Schneider, F. Götz, G. Bierbaum, H.-G. Sahl, Mol. Microbiol. 1998, 30, 317-327; b) A. H. Katz, C. E. Cau- 
field, Curr. Pharm. Des. 2003, 9, 857-866; c) A. L. Koch, Clin. Microbiol. Rev. 2003, 16, 673-687.

[8] E. Breukink, B. de Kruijff, Nat. Rev. Drug Discovery 2006, 5, 321 - 332

[9] a) S.-T. D. Hsu, E. Breukink, B. de Kruijff, R. Kaptein, A. M. J. J. Bonvin, N. A. J. van Nuland, Biochemistry 2002, 41, 7670-7676; b) S.-T. D. Hsu, E. Breukink, E. Tischenko, M.A.G. Lutters, B. de Kruijff, R. Kaptein, A. M. J. J. Bonvin, N. A. J. van Nuland, Nat. Struct. Mol. Biol. 2004, 11 $963-967$.

[10] a) I. Wiedemann, E. Breukink, C. van Kraaij, O. P. Kuipers, G. Bierbaum, B. de Kruijff, H.-G. Sahl, J. Biol. Chem. 2001, 276, 1772-1779. Recently an alternative mechanism of antibacterial activity was described: b) H. E. Hasper, N. E. Kramer, J. L. Smith, J. D. Hillman, C. Zachariah, O. P. Kuipers, B. de Kruijff, E. Breukink, Science 2006, 313, 1636-1637.

[11] D. Twomey, R. P. Ross, M. Ryan, B. Meaney, C. Hill, Antonie van Leeuwenhoek 2002, 82, 165-185.

[12] a) N. Ghalit, D. T. S. Rijkers, J. Kemmink, C. Versluis, R. M. J. Liskamp, Chem. Commun. 2005, 192-194; b) N. Ghalit, A. J. Poot, A. Fürstner D. T. S. Rijkers, R. M. J. Liskamp, Org. Lett. 2005, 7, 2961-2964; c) N. Ghalit, D. T. S. Rijkers, R. M. J. Liskamp, J. Mol. Catal. A 2006, 254, 68-77; d) N. Ghalit, J. Kemmink, H. W. Hilbers, C. Versluis, D. T. S. Rijkers, R. M. J. Liskamp, Org. Biomol. Chem. 2007, 5, 924-934; e) V. R. Pattabiraman, J. L. Stymiest, D. J. Derksen, N. I. Martin, J. C. Vederas, Org. Lett. 2007, 9, $699-702$.

[13] An alkene-bridge as a mimic of a disulfide bond has been described a) S. J. Miller, H. E. Blackwell, R. H. Grubbs, J. Am. Chem. Soc. 1996, 118, 9606-9614; b) R. M. Williams, J. Liu, J. Org. Chem. 1998, 63, 2130-2132 c) Y. Gao, P. Lane-Bell, J. C. Vederas, J. Org. Chem. 1998, 63, 2133-2143 d) J. L. Stymiest, B. F. Mitchell, S. Wong, J. C. Vederas, Org. Lett. 2003, 5 47-49; e) A. N. Whelan, J. Elaridi, M. Harte, S. V. Smith, W. R. Jackson, A. J. Robinson, Tetrahedron Lett. 2004, 45, 9545-9547; f) J. L. Stymiest, B. F. Mitchell, S. Wong, J. C. Vederas, J. Org. Chem. 2005, 70, 7799-7809; g) A. N. Whelan, J. Elaridi, R. J. Mulder, A. J. Robinson, W. R. Jackson, Can J. Chem. 2005, 83, 875-881; h) I. Berezowska, N. N. Chung, C. Lemieux B. C. Wilkes, P. W. Schiller, Acta Biochim. Pol. 2006, 53, 73-76; i) D. J. Derksen, J. L. Stymiest, J. C. Vederas, J. Am. Chem. Soc. 2006, 128 $14252-14253$; j) J. Elaridi, J. Patel, W. R. Jackson, A. J. Robinson, J. Org. Chem. 2006, 71, 7538-7545; k) I. Berezowska, N. N. Chung, C. Lemieux B. C. Wilkes, P. W. Schiller, J. Med. Chem. 2007, 50, 1414-1417; I) A. J. Robinson, J. Elaridi, B. J. van Lierop, S. Mujcinovic, W. R. Jackson, J. Pept. Sci. 2007, 13, 280-285; m) S. Jiang, P. Li, S.-L. Lee, C. Y. Lin, Y.-Q. Long, M. D. Johnson, R. B. Dickson, P. P. Roller, Org. Lett. 2007, 9, 9-12.

[14] For general reviews concerning ring-closing metathesis: a) R. H. Grubbs, S. Chang, Tetrahedron 1998, 54, 4413-4450; b) S. K. Armstrong, J. Chem. Soc. Perkin Trans. 1 1998, 371-388; c) A. Fürstner, Angew. Chem. 2000 112, 3140-3172; Angew. Chem. Int. Ed. 2000, 39, 3012-3043; d) T. M. Trnka, R. H. Grubbs, Acc. Chem. Res. 2001, 34, 18-29.

[15] R. D. Süssmuth, R. W. Jack, G. Jung in Houben-Weyl, Vol. E22b: Synthesis of Peptides and Peptidomimetics (Eds.: M. Goodman, C. Toniolo, L. Mo roder, A. Felix), Thieme, Stuttgart, 2003, pp. 184-214.

[16] The synthesis of this amino acid was performed according to: a) $\mathrm{K}$. Sakaguchi, H. Suzuki, Y. Ohfune, Chirality 2001, 13, 357-365; b) I. Izzo, E. Avallone, L. Della Corte, N. Maulucci, F. De Riccardis, Tetrahedron: Asymmetry 2004, 15, 1181-1186; c) Y. Morimoto, M. Takaishi, T. Kinoshita, K. Sakaguchi, K. Shibata, Chem. Commun. 2002, $42-43$.

[17] W. C. Chan, H. M. Dodd, N. Horn, K. Maclean, L.-Y. Lian, B. W. Bycroft M. J. Gasson, G. C. K. Roberts, Appl. Environ. Microbiol. 1996, 62, $2966-$ 2969.

[18] Replacement of methionine by norleucine residues is a commonly carried-out isosteric replacement, which avoids impurities caused by oxidation of methionine residues. This methionine residue can also be substituted by a lysine residue without loss of biological activity, see ref. [9].

[19] M. Scholl, S. Ding, C. W. Lee, R. H. Grubbs, Org. Lett. 1999, 1, 953-956.

[20] Two reports deal with the total synthesis of nisin: a) K. Fukase, M. Kitazawa, A. Sano, K. Shimbo, H. Fujita, S. Horimoto, T. Wakamiya, T. Shiba, Tetrahedron Lett. 1988, 29, 795-798; b) K. Fukase, M. Kitazawa, A. Sano K. Shimbo, S. Horimoto, H. Fujita, A. Kubo, T. Wakamiya, T. Shiba, Bull.
Chem. Soc. Jpn. 1992, 65, 2227-2240. Other examples of lanthionine syntheses: c) P. L. Toogood, Tetrahedron Lett. 1993, 34, 7833-7836; d) S. Burrage, T. Rayham, G. Williams, J. W. Essex, C. Allen, M. Cardno, V. Swali, M. Bradley, Chem. Eur. J. 2000, 6, 1455-1466; e) N. M. Okeley, Y. Zhu, W. A. van der Donk, Org. Lett. 2000, 2, 3603-3606; f) H. Zhou, W. A. van der Donk, Org. Lett. 2002, 4, 1335-1338; g) Y. Zhu, M. D. Gieselman, H. Zhou, O. Averin, W. A. van der Donk, Org. Biomol. Chem. 2003, 1, 3304-3315; h) M. Matteucci, G. Bhalay, M. Bradley, Tetrahedron Lett. 2004, 45, 1399-1401; i) S. Bregant, A. B. Tabor, J. Org. Chem. 2005 70, 2430-2438; j) X. Zhang, W. Ni, W. A. van der Donk, J. Org. Chem. 2005, 70,6685-6692; k) R. S. Narayan, M. S. VanNieuwenhze, Org. Lett. 2005, 7, 2655-2658; I) W. A. van der Donk, J. Org. Chem. 2006, 71 $9561-9571$.

[21] M. S. Sanford, J. A. Love, in Handbook of Metathesis, Vol. 1 (Ed.: R. H. Grubbs), Wiley-VCH, Weinheim, 2003, pp. 112-131.

[22] This technique was used to assign the different coupling constants; see also ref. [13].

[23] To obtain fragment $A$ on a larger scale $(3.5 \mathrm{mmol})$ we also synthesized pentapeptide 9 in solution starting from $\mathrm{HCl} \cdot \mathrm{H}-\mathrm{Alg}$-OMe. During the solution-phase synthesis the intermediates were purified by aqueous acid/base extractions; finally, pentapeptide 9 was obtained in $70 \%$ overall yield.

[24] It was found that the formation of diketopiperazines could be avoided if a solution of diethylamine in THF was used. In the first instance we used an aqueous solution of dimethylamine: removal of the solvent at elevated temperature resulted in premature diketopiperazine formation.

[25] T. Curtius, Ber. Dtsch. Chem. Ges. 1890, 23, 3023-3033.

[26] J. Honzl, J. Rudinger, Collect. Czech. Chem. Commun. 1961, 26, $2333-$ 2343.

[27] W. König, R. Geiger, Chem. Ber. 1970, 103, 788-798.

[28] T. Shioiri, K. Ninomiya, S.-I. Yamada, J. Am. Chem. Soc. 1972, 94, $6203-$ 6205.

[29] E. J. Corey, I. Székely, C. S. Shiner, Tetrahedron Lett. 1977, 18, 3529-3532.

[30] a) S. Su, H. Kakeya, H. Osada, J. A. Porco, Jr., Tetrahedron 2003, 59, 8931 -8946; b) S. Gorohovsky, S. Meir, V. Shkoulev, G. Byk, G. Gellerman Synlett 2003, $1411-1414$

[31] Before the peptides could be characterized by MS/MS, the protecting groups were removed, see:J. F. Reichwein, B. Wels, J. A. W. Kruijtzer, C. Versluis, R. M. J. Liskamp, Angew. Chem. 1999, 111, 3906-3910; Angew. Chem. Int. Ed. 1999, 38, 3684.

[32] M. Bodanszky, J. Martinez, Synthesis 1981, 333-356.

[33] a) U. Kazmaier, C. Hebach, A. Watzke, S. Maier, H. Mues, V. Huch, Org. Biomol. Chem. 2005, 3, 136-145; b) A. B. Smith III, E. F. Mesaros, E. A. Meyer, J. Am. Chem. Soc. 2005, 127, 6948-6949.

[34] H. E. van Heusden, B. de Kruijff, E. Breukink, Biochemistry 2002, 41, $12171-12178$.

[35] H. E. Hasper, B. de Kruijff, E. Breukink, Biochemistry 2004, 43, 11567 11575.

[36] W. C. Chan, M. Leyland, J. Clark, H. M. Dodd, L.-Y. Lian, M. J. Gasson, B. W. Bycroft, G. C. K. Roberts, FEBS Letters 1996, 390, 129-132.

[37] F. Mohamadi, N. G. J. Richards, W. C. Guida, R. Liskamp, M. Lipton, C. Caufield, G. Chang, T. Hendrickson, W. Clark Still, J. Comput. Chem. 1990, 11, 440-467.

[38] E. von Arx, M. Faupel, M. J. Brugger, J. Chromatogr. A 1976, 120, $224-$ 228.

[39] R. Knorr, A. Trzeciak, W. Bannwarth, D. Gillessen, Tetrahedron Lett. 1989 30, $1927-1930$.

[40] B. Castro, J. R. Dormoy, G. Evin, C. Selve, Tetrahedron Lett. 1975, 16, $1219-1222$.

[41] E. Kaiser, R. L. Colescott, C. D. Bossinger, P. I. Cook, Anal. Biochem. 1970 34, 595-598.

Received: May 7, 2007

Published online on August 2, 2007 